\title{
MEVLUD IZMEĐU LIJEPOG OBIČAJA (SUNNETUN HASENETUN) I ZABRANJENE NOVOTARIJE (BIDA'TUN SEJJIETUN)
}

\section{Sažetak}

Svake godine u tradiciji muslimana mjesec rebiul-evvel se posveti pamćenju $i$ sjećanju na Muhammeda, a.s., prigodnim programima ili tkzv. Mevludima.

Svake godine dolaskom mjeseca rebiu'l-evvela, u kojem je roden Allahov Poslanik, a.s., nanovo se aktualizira $i$ pravno šerijatski spor oko pitanja obilježavanja $i$ slavljenja rodendana Muhammeda, a.s., organizovanjem proslave Mevluda, kojeg ortodoksna, puritanistička ulema drži zabranjenom, ružnom novotarijom $i$ inovacijom u vjeri (bida'tun sejjie), koju se ljudi uzakonili, inovirali kao dan praznikovanja slijedeći običaje drugih, kao što su kršćani, nevjernici itd.; dok ga druga, savremena ulema drže lijepim $i$ pohvalnim činom (sunnetun hasenetun) koji ima svoje opravdanje i koristi kroz praksu i ostvarivanje nekih dozvoljenih vidova ibadeta, kao sto je učenje Kur'ana, donošenje salavata, učenje dova $i$ zikra te podsjećanje na siru, tj. životopis Muhammeda, a.s., kroz vjerska predavanja, vaz i sl.

$U$ savremenim uvjetima ta manifestacija se može iskoristiti po našim džamijama i ď̌ematima u obrazovne, odgojne i misionarske svrhe, kao izraz ljubavi i volidbe Allahovog Poslanika, a.s., i kao tradicija i običaj savremenog pamćenja i sjećanja na Allahovog Poslanika, a.s., njegovo učenje $i$ njegovu Misiju, a ne da se Mevlud uzima kao vjerska, obredna manifestacija, sto je nažalost čest slučaj u praksi.

Ključne riječi: Mevlud, ružna novotarija (bida'tun sejjie), lijep običaj (sunnetun hasenetun), ulema, kultura pamćenja i sjećanja, tradicija, običaj.

\section{Uvod}

Činjenica je da Uzvišeni Allah nije prepustio slučaju pamćenje, sjećanje i spominjanje svoga miljenika Muhammeda, a.s.; nije ostavio i

\footnotetext{
${ }^{1}$ Islamski pedagoški fakultet u Bihaću.
} 
prepustio slučaju hoće li se muslimani svijeta sjetiti njega pa mu izmisliti mevlud i uvesti u praksu pompezno slavljenje njegovog rođendana kroz hiljade godina kao novotariju ili kao običaj i tradiciju, kao što su drugi uveli svojim velikanima; to sve nije prepustio slučaju nego je u svekolikoj ovosvjetskoj kulturi sjećanja i pamćenja Uzvišeni Allah, dž.š., odredio i koncipirao čitav, neponovljiv, nenadmašan sistem u kojem je Njegov Miljenik i Poslanik, Muhammed, a.s., osoba koja će biti

1. doktrinarno (tevkifi) ali i

2. ljudski (tevfiki) centralna ličnost i objekt pamćenja i sjećanja $u$ istoriji čovječanstva.

Muhammed, a.s., spomenut je u Prvom temelju vjere, Šehadetu, odmah uz formulu monoteizma. Buharija, Muslim i drugi hadiski autoriteti zabilježili su predaju, od Ibni Omera, r.a., koja taksativno pobrojavajući pet temelja u sistemu islama, a prvo spominje dva šehadeta:

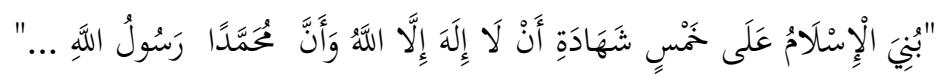

Pet je temelja islama: Svjedočanstvo da nema boga sem Allaha, i da je Muhammed Allahov Poslanik...

Dakle, početak vjere nekog vjernika započinje sa Šehadetom u kojem se izgovara i sjeća ime Muhammeda, a.s., spomenuto uz samo Božije ime. Ime Muhammeda, a.s., svakodnevno se pamti i sjeća ga se svaki musliman praktičar, izgovarajući u svojim dnevnim molitvama, kroz doktrinarne forme salavata, makar trideset pet puta dnevo, samo ako klanja obavezne farz/namaze, ili čak stotinjak puta ako klanja i namaske sunnete, kroz zikr i učenje Et-Tehijjatu i salavata koji se uče na sjedenju namaza, a što su zabilježili Buhari i Muslim od Ka'ba b. A'džureta, r.a.:

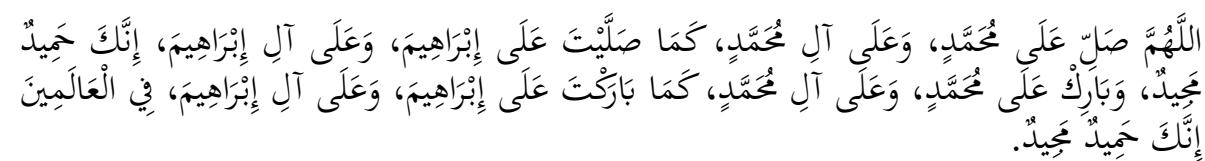

Gospodaru, blagoslovi Muhammeda i Muhammedovu porodicu, kao što si blagoslovio Ibrahima $i$ njegovu porodicu, $i$ budi zadovoljan Muhammedom i porodicom Muhammeda, kao što si bio zadovoljan 
Ibrahimom i njegovom porodicom. Gospodaru, Ti si uistinu hvaljen $i$ slavljen. $^{2}$

To svakodnevno sjećanje na ime i ličnost Muhammeda, a.s., započinje svakog dana, na sabahu, kada vjernik klanja sabah namaz pa se onda nastavlja i na podne, pa na ikindiji, na akšamu i na jaciji. Pored spomenutog izgovaranja i sjećanja čini se i dodatno, javno sa minareta kao simbol da je neko mjesto muslimansko, pet puta dnevno, u islamskim mjestima i gradovima kada se razliježu riječi ezana, a onda i u ikametu unutar džamije ili porodičnih kuća sa kojim se starta sa farz namazom. Potom se ponovo ovo ime spominje u dovi iza ezana. Prema tome svaki vjernik od vremena kada postane vjernikom, primanjem islama ili punoljetstvom, ako je rođen u islamu, pamti, spominje i sjeća se Muhammeda, a.s., stotine puta svakodnevno do svoje smrti. Pomnožimo ovo sa članovima islamskog ummeta, koji je najbrojniji ummet na zemaljskoj kugli. Rezultat je naprosto fantastičan! Zaista, ako znamo da je islamski ummet, najbrojniji na zemaljskoj kugli, onda možemo otkriti da se ime Muhammeda, pamti, sjeća i spominje svakodnevno u desetinama ili stotinama milijardi puta. I to se ponavlja svaki dan, u istorijskom rasponu već preko četrnaest vijekova. Nijedan smrtnik, nijedno stvoreno biće, nije predmet ovakve kulture pamćenja i sjećanja kroz istoriju svijeta. Prema tome bespredmetno je dalje uopće raspravljati o tome, pored toga što se Muhammed, a.s. u kulturi pamćenja i sjećanja spominje stotine milijardi puta svakodnevno u islamskom ummetu po doktrinarnoj osnovi, bespredmetno je treba li uz to da se po ljudskoj inovaciji - jer mevlud nije postojao u prva tri/četiri stoljeća islama - spominje i još jednom manifestcijom godišnje kao što je Mevlud. Ta rasprava je - kako god tretirali mevlud, kao lijep islamski običaj, što smatraju neki ili kao zabranjenu novotariju, što smatraju drugi, ili kao manifestaciju koja može poslužiti u današnjem vremenu kao vid sjećanja i pamćenja na Misiju s kojom je došao Allahov Poslanik, a.s., uz ovo nebrojano doktrinarno i praktično sjećanje na Muhammeda, a.s., koje svaki vjernik praktičar pamti spominjući Muhammeda, a.s., u svojim ibadetima - samo ono što zamagljuje horizont tako da se od šume ne vidi drveće, odnosno od jednog slučaja se ne vidi milijarde drugih.

${ }^{2}$ Bilježe ga Buhari (3370) i Muslim (406). 
Razmatrajući pitanje Mevluda u ovome radu sa šerijatsko-pravnog aspekta, zbog njegove prirode, nismo mogli samo eksplikacijom praktično pravnih šerijatskih propisa dozvole ili zabrane, zbog toga što ovo pitanje zahtijeva da se u njegovom razmatranju uzme u obzir i njegov savremeni kompleksni aspekt te i njegova tradicijska, običajna, civilizacijska i kulturna vrijednost.

\section{Značenje salavata i selama, doktrinarno i za onoga ko ih donos $\mathrm{i}^{3}$}

Poznato je u islamskoj doktrini da ako neko ikada u svom životnom vijeku izgovori iskreno Šehadet koji sadrži i ime Muhammeda, a.s., obećaje mu se da će ga Uzvišeni Allah zabraniti vatri.

Katade prenosi od Enes b. Malika koji kazuje da je Allahov Poslanik, a.s., jedne prilike jahao na istoj jahalici zajedno sa Mua'zom b. Džebelom kojega je tri puta zovnuo, a ovaj mu se odazvao i nakon toga mu rekao:

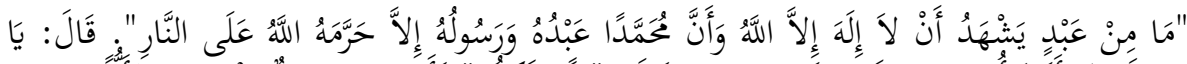

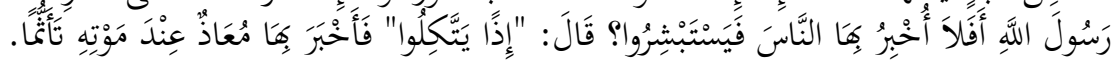

,Svakog Božijeg roba koji posvjedoči: Nema boga sem Allaha, $i$ Muhammed je Božiji rob i Poslanik, Uzvišeni Allah će zabraniti džehennemskoj vatri.' Mu'az reče: Allahov Poslaniče, zašto ne bih obavijestio ljude pa da se raduju tome.' On reče: ,Tada bi se samo na to oslonuli.' Mu'az je o tome obavijestio tek na samrti bojeći se da ne bude griješan za skrivanje istine. ${ }^{4}$

Kod izrazite većine uleme donošenje salavata na Poslanika, a.s., znači, od Uzvišenog Allaha milost, od meleka da traže oprost, a od ljudi da dove za njega.

Kod ostalih, kao što je Ebul-A'lije od klasične uleme, Ibnul-Kajjima od potonje i Ibn U'sejmina od savremene, donošenje salavata na Poslanika, a.s., pretpostavlja da on bude spomenut $i$ pohvaljen među nebeskim stanovnicima od Uzvišenog, Njegovom milošću $i$ rahmetom, a u pogledu meleka i vjernika da oni dove za njega...

\footnotetext{
${ }^{3}$ Vidi više: www.islamqa.info/ar/180852 (pristupljeno 10. januar, 2016.).

${ }^{4}$ Bilježe ga Buhari (126), Muslim (50) i Ahmed (21440).
} 
Šejh Muhammed b. Salih El-U'sejmin navodi:

Riječi: Salli a'la Muhammed!, znače, milost od Uzvišenog, od meleka da traže oprost $i$ od ljudi da traže dovu. Međutim, salavat je specifičnijeg značenja od rahmeta (milost), jer se milost (rahmet) može tražiti za bilo kojeg vjernika, međutim salavat se traži samo za poslanike. Prema tome da je milost i salavat identičnog značenja, onda ne bi bilo spora uleme oko toga da li je dozvoljeno salavat donositi za obične ljude osim poslanika, pa su se razišli oko tog pitanja, dok su na konsezusu da se može doviti i tražiti milost za bilo kojeg vjernika. Uostalom, Uzvišeni je rekao:

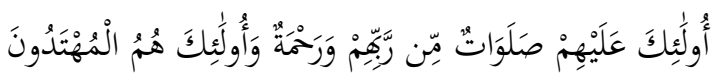

Njih čeka oprost od Gospodara njihova (salavat) i milost (oprost); oni su na Pravome putu! $!^{5}$

Uzvišeni je spomenuo i salavat $i$ rahmet što po pravilima komentara Kur'ana i značenja jezika upućuje na to da to nisu sinonimi. Prema tome, kada se kaže: Allahumme salli a'lejhi... znači: Pohvali ga $i$ spomeni među nebeskim stanovnicima, odnosno pred odabranim melekima... ${ }^{6}$

A kada se kaže: Es-Selamu a'lejhi (sallallahu a'lejhi ve sellem), to je dova sa željom da on bude spašen u životu, spašen u svojoj vjeri, spašen u svome kaburu i spašen na Sudnjem danu.

Uzvišeni je rekao:

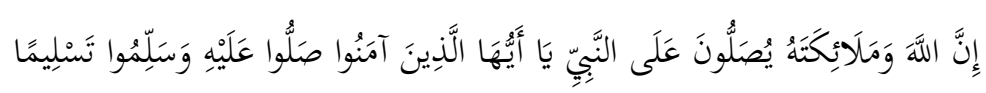

Allah i meleki Njegovi donose salavat (blagosilju Vjerovjesnika). O vjernici, (donesite salavat na njega) blagosiljajte ga i vi $i$ šaljite mu pozdrav! ${ }^{\prime}$

Ovdje teslim znači: da se dovi/traži selamet za njega, a.s., od svakog vida nesreće. Ovakav vid dove-selameta nije samo za vrijeme života, jer strah i nesreće tek se nastavljaju poslije smrti, nego je dova za spasselamet i u zagrobnom životu, na Sudnjem danu i kod prelaska Sirat

\footnotetext{
${ }^{5}$ Kur'an, El-Bekare, 157.

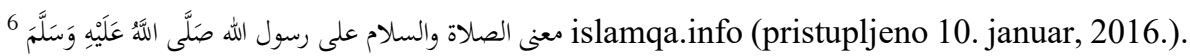

${ }^{7}$ Kur'an, El-Ahzab, 56.
} 
ćuprije za koju je došla hadiska dova: Allahumme sellim sellim! (Allahu moj spasi, daj selamet!). Prema tome ovom dovom se traži spas Poslanika, a.s., od strahota mjesta i situacija (ovodunjalučki i eshatološki)...

Ibni Tejmije je rekao: Poslaniku, a.s., donosi se selam kao da je prisutan pred tobom. Njegovi ashabi su govorili: Selam tebi! (EsSelamu a'lejke), iako ih on ne čuje, ili su bili čak u drugom mjestu! Tako i mi kažemo: Selam tebi! (Es-Selamu a 'lejke), iako smo daleko od njega i nismo čak ni iz njegovog vremena. ${ }^{8}$

Salavat na Muhammeda, a.s., doktrinarno, jedan je vid preferiranog obredoslovlja koje nas približava Uzvišenom i sa kojim se Njemu može umiliti neko od vjernika, a On Uzvišeni je naredio vjernicima da donose salavat i selam na njega, a.s., obavjestivši ih prije toga, da čak i On Uzvišeni, zajedno sa melekima, isto to čini:

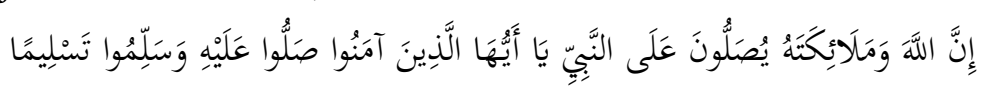

Allah i meleki Njegovi donose salavat (blagosilju Vjerovjesnika). O vjernici, (donesite salavat na njega) blagosiljajte ga i vi $i$ šaljite mu pozdrav! ${ }^{9}$

Osim toga, i Allahov Poslanik, a.s., stimulisao je i podsticao na taj čin, proklamovao da je to obredoslovlje čija vrijednost je uvećana desetorostruko, uzrokuje oprost grijeha i postizanje potreba, pa je rekao u vjerodostojnoj predaji, po ocjeni Albanija, a koju je zabilježio Nesai (1297.):

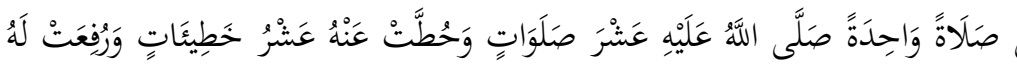

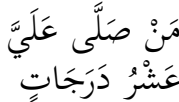

Ko na mene donese salavat jedanput, Uzvišeni Allah donese na njega deset puta, pobriše mu se deset grijeha i uzvisi za deset stepena.

\footnotetext{
${ }^{8}$ Muhammed b. Salih el-U'sejmin, Eš-Šerhul-mumti'ua'la zadil-mestekni'i, Dar Ibni Dževzi lin-nešri vet-tevzi'i, 3/163-164.

${ }^{9}$ Kur'an, El-Ahzab, 56.
} 
Prema tome vrijednost donošenja salavata na Allahovog Poslanika, a.s., nije samo korist Poslaniku, a.s., nego se vraća i na onoga ko salavat donosi ${ }^{10}$.

\section{Muhammed, a.s., u kulturi pamćenja i sjećanja}

- U svjetskoj kulturi pamćenja i sjećanja svake godine neki utjecajni listovi prave rang liste najutjecajnijih osoba u svijetu, a američki prof. Majkl H. Hart je 1978. godine napisao knjigu „100“ u kojoj je, a onda i u njenom ponovljenom izdanju, Muhammeda, a.s., poslanika islama, stavio na prvo mjesto liste najutjecajnijih na istoriju čovječanstva, odnosno Muhammed, a.s., je time proglašen najvećim učiteljem koji je djelovao na ljude $\mathrm{i}$ istoriju svijeta. To se moglo desiti samo zbog toga što je on, a.s., bio Allahov Poslanik i što islam ima takav božanski nenadmašan sistem koji se praktikuje.

- Isto tako, svake godine dolaskom mjeseca rebiu'l-evvela, u kojem je rođen Allahov Poslanik, a.s., nanovo se potegne pitanje dozvoljenosti obilježavanja i slavljenja rođendana Muhammeda, a.s., na običajni, tradicijski način učenjem i organizovanjem proslave Mevluda, kojeg jedni drže zabranjenom, ružnom novotarijom i inovacijom u vjeri, koja se ne prihvata, jer je Uzvišeni Allah niti njegov Poslanik, a.s., nisu uzakonili, isto tako ljudi određuju, inoviraju dan praznikovanja koji nije vjerom ustrojen, što predstavlja vid slijeđenja drugih, kao što su kršćani, nevjernici itd.; dok drugi drže Mevlud i obilježavanje rođenja Poslanika, a.s., lijepim i pohvalnim činom u vjeri koji ima svoje opravdanje i koristi kroz praksu i ostvarivanje nekih dozvoljenih vidova valjanog ibadeta, kao što je učenja Kur'ana, donošenjem salavata na Pejgambera, dova i zikra, te podsjećanje na siru, tj. životopis Muhammeda, a.s., kroz vjerska predavanje, vaz i sl.

Nesporna je činjenica da obilježavanje, učenje i priređivanje Mevluda spada u bošnjačku kulturu pamćenja i sjećanja povodom rođendana Muhammeda, a.s., nastao u običajima i tradiciji islama.

10 فضل الإكثار من الصالاة على النبى صلى الله عليه وسلم ... فttps://islamqa.info/ar/128455

(pristupljeno 10. januar, 2016.). 
Antun Hangi, opisujući običaje i tradiciju Bošnjaka, stavlja Mevlud odmah uz dva Bajrama: Muslimani imaju i nekoliko blagdana, a najveći su Ramazan-bajram, Kurban-bajram i Mevlud. ${ }^{11}$

U praktičnom opisu tradicije i običaja Mevluda Hangi kaže:

Mevlud ili bolje Mevludi šerifje arapska riječ, a znači rođenje. Mevludi šerif slavi se na uspomenu one noći kada se je Muhammed pejgamber rodio. Muhammed pejgamber bio je sin Abullahov, unuk AbdulMutallibov, a praunuk Hašimov. On potječe od plemnitog roda Kurejša, a rodio se je u Mekki, u ponejeljak 12. rebiul evela.

One noći kada se je Muhammed pejgamber rodio dogodilo se je više čudesa. Sva ta čudesa učinio je Bog zato da pokaže svijetu da je Muhammed njegov ljubimac i najveći pejgamber, te da donosi na svijet čistu nauku njegovu. Mjesec u kome se je Muhammed pejgamber rodio, zvao se je, kako rekosmo, rebiul evel, ali to ime nosi on danas samo kroz prvih jedanaest dana, naime do rođendana Muhammed pejgambera. Od onda pa do konca zove se Mevlud... ${ }^{12}$

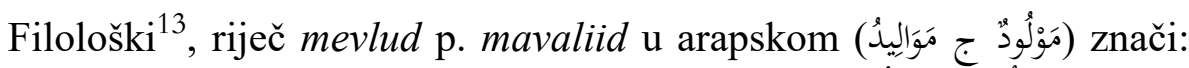

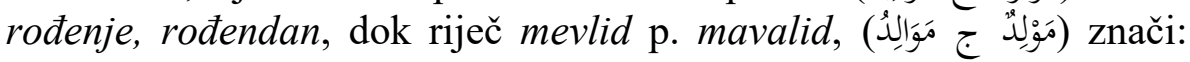
mjesto rođenja, rođenje, rođendan. \&l-Mevlidun-nebevijj (ili:

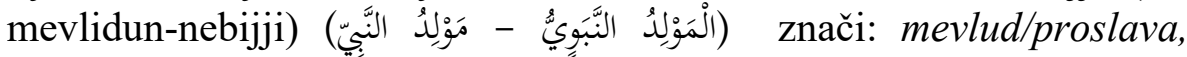
obilježavanje Muhammedova, a.s., rođenja.

Iz citata A. Hangija razumije se da Mevlud ima polisemno značenje, a akademik, dr. Karić tu riječ kod Bošnjaka svodi na ova tri značenja:

1. Mevlud u značenju spjeva, pjesme o Muhammedu, a.s. (najčešće o njegovom rođenju i najvažnijim detaljima njegova poslaničkog života);

2. Mevlud u značenju svečanosti kojom se obilježava rođendan Muhammeda, a.s.;

3. Mevlud u značenju svečanosti kojom se obilježava bilo koji značajan događaj u životu muslimana ili njegove obitelji (mevludi u povodu

11 Antun Hangi, Život i običaji Muslimana u Bosni i Hercegovini, Dobra knjiga, Sarajevo, 2009., str. 31.

12 Antun Hangi, Život i običaji Muslimana u Bosni i Hercegovini, str. 49.

13 Teufik Muftić, Arapsko srpskohrvatski riječnik, korijen riječi: ولد 
useljenja u kuću ili stan, mevludi u povodu ženidbe, mevludi u znak sretnog ispraćaja sina u vojsku, mevludi kao suptilni znak /društvenog,vjerskog itd./ prestiža onih domaćina $i$ domova koji mevludske svečanosti priređuju, itd. ${ }^{14}$.

U spomenutom citatu Hangija spomenuto je i još jedno značenje Mevluda u tradiciji i običajima Bošnjaka i to da je:

4. Mevlud naziv mjeseca u kojem je rođen Muhammed pejgamber.

Što se tiče Mevluda kao spjeva, pjesme ili specifičnog oblika duhovnog, pobožnog književnog stvaralaštva kod nas u našem bošnjačkom miljeu teško je naći oblik književnog stvaralaštva u kojem su osobenost $i$ izražajnost bošnjačkog duhovnog bića tako prepoznatljive kao što su to u mevludu. I ne samo to, mevlud je zadržao vrlo značajno mjesto i ulogu $u$ procesu uobličavanja $i$ snaženja bošnjačkog narodnog bića pečatljivije od mnogih drugih književnih oblika. ${ }^{15}$

O Mevludu se govori i kao simbolu bošnjačkog identiteta, simbolu vjere $i$ vjerozakonskom obredu... Ozbiljnijom analizom veze koja postoji između islama i bošnjačke nacije dolazi se do zaključka da religijski obredi, kakvi su mevludi, pored dva bajrama i hidžretske nove godine, u sebi nose elemente simbola etničkog identiteta. ${ }^{16}$

Muhamed Filipović smatra da je "mevlud tradicionalna i legitimna pjesnička forma $u$ kojoj se slavi rođenje, život $i$ djelo Poslanika Muhammeda i da je ono, kao takvo, dio njegove baštine i dio njegovog duhovnog svijeta.

Međutim, kako je dobro primijetio Mevlud nije ritualni čin, ali Bošnjaci imaju razloga da od mevluda načine svoju narodnu proslavu. Potom zaključuje: Imamo sve razloge da njegujemo mevlud kao pjesničku formu, čak $i$ da organiziramo natjecanja u pisanju $i$ u recitiranju, pa i u predstavljanju događanja iz mevluda za naš narod. Mi imamo pravo i dužnost da tu tradiciju, koja osnažuje naše povjerenje $u$ sebe $i$ u opravdanje našeg postojanja, smatramo bitnom za naš

\footnotetext{
${ }^{14}$ Mevlud www.becopdx.com/index.php/aktivnosti/mevlud (pristupljeno 10. januar, 2016.).

15 Ibid.

${ }^{16}$ Ibid. (Vidjeti citat E. Kujundžića)
} 
duhovni život. Nas ne treba da zbunjuje činjenica da smo mi prihvatili zapadni pjesnički kodeks. On nije u suprotnosti sa našim tradicionalnim pjesničkim prosedeom, inspirisanim na arapskoj $i$ perzijskoj književnosti. Kad su mogli Dante $i$ Goethe da se inspiriraju arapskom $i$ perzijskom književnošću, kada su mogli minstreli i trubaduri da se inspiriraju $i$ uče na muallakama, zašto ne bi $i$ naša suvremena književnost imala taj smisao i ulogu, tj. smisao mosta između dvije velike tradicije koje uostalom potječu iz istog duhovnog ljudskog izvora? ${ }^{17}$

U svim svojim značenjima, u duhovnoj kulturi Bošnjaka, mevlud ima posebno mjesto. Iako se ne nalazi među šest temeljnih postulate islamskog vjerovanja niti spada u pet zadatih islamskih dužnosti (šartove), postao je dio bošnjačke duhovne tradicije više snagom narodne prakse nego imperativom unutarnjeg vjerskog poticaja. ${ }^{18}$

Na našim prostorima, zbog specifičnih shvatanja, tradicije i običaja ali pod uticajem tradicije iz Turske, učenje mevluda praktikovano je povodom raznih prigoda u toku godine. Ta praksa se zadržala $i$ do danas. U slučaju Bošnjaka, sve ovo pokazuje $i$ potvrđuje da riječ mevlud označava raznolike društvene institucije, književne žanrove, folklorne izraze. Muhamed Filipović kaže da mevlud kao pjesnička forma ima svoj kanon - kako u sadržajnom, tako i u formalnom smislu. Svakako da on potiče iz bogate arapsko-turske tradicije, ali se na njegovoj formi i sadržini (osobito u onom obliku u kojem se, preko osmanlijskih uticaja etablirao kod nas), vide i jaki uticaji perzijske $i$ osmanske literature, koja je i sama bila pod snažnim perzijskim uticajem. Kao takav, mevlud je dobio strogu formu i unaprijed zadani sadržaj, u kojem je pjesnička imaginacija bila ograničena, jedino, na način izražavanja, metafore, bogatstva jezika i fraze, ali nije smjela odstupati od onoga što je već bilo kanonizirano ... 19

Godine 1878. štampan je prvi spjev Mevluda na bosanskom jeziku u Skoplju od autora hafiza Saliha ef. Gaševića, kolašinskog prvaka i

\footnotetext{
${ }^{17}$ Mevlud www.becopdx.com/index.php/aktivnosti/mevlud (pristupljeno 10. januar, 2016.).

18 Ibid.

${ }^{19}$ Mevlud www.becopdx.com/index.php/aktivnosti/mevlud (pristupljeno 10. januar, 2016.).
} 
kajmekama, koji je na bosanski preveo i prepjevao mevludski spjev Sulejmana Čelebije. Pojavom Mevluda na bosanskom jeziku, postali su popularni među muslimanskim masama, derogiraju se Mevludi pisani i učeni na arapskom i turskom, a učenje mevluda na bosanskom (džematski i porodični krug) postala je opća praksa u Bosni i Hercegovini i Sandžaku.

Osim Mevluda Gaševića, kod nas se pojavilo još nekoliko od kojih su najpoznatiji, Mevlud Safvet bega Bašagića, Arifa ef. Sarajlije, hafiza Seida ef. Zenunovića iz Koraja i profesora Rešada Kadića.

Naravno, treba imati u vidu Mevlud kao pisanu riječ, odnosno spjev, i Mevlud kao praznik, manifestaciju obilježavanja rođenja Muhammeda a.s. U spjevu Mevluda, kao i u svim proslavama Mevluda u tradiciji i običajima Bošnjaka u centru svega bio je Poslanik, a.s., čin njegovog rođenja, poslanstvo i ukazivanje na znakove njegove Misije, sam čin Objave i njen osnovni sadržaj, njegovo uznesenje na Mi'radž, te konačno njegova smrt i preseljenje. To sve će u biti ostati kanonizirana forma Mevluda kao pisanih, odnosno pjesničkih djela na bosanskom jeziku.

Što se tiče Mevluda kao proslave, obilježavanja i slavljenja rođenja Muhammeda, a.s., o tome ćemo dati šerijatsko pravni aspekt jer se na njegovu legitimnost i praksu ortodoksno u puritističkim islamskim krugovima i miljeima nije gledalo i ne gleda blagonaklono tretirajući ga novotarijom, koje nije bilo u vrijeme Poslanika, a.s., pa čak ni u sva tri prva stoljeća islama koja predstavljaju zlatno doba islamske misli i prakse. Zbog toga je neophodno dati šerijatsko pravni aspekt Mevluda.

\section{Šerijatsko pravni status obilježavanja Mevluda u islamu}

Po pitanju obilježavanja rođenja plemenitog Poslanika, a.s., islamski pravnici su se razišli na dvije grupe dijametralno suprostavljenih stavova, od kojih prva smatra da je to zabranjena novotarija, a druga da to spada u dozvoljeno obilježavanje i praznikovanje, koje ima svoje koristi, dobra i za koje će se imati čak i eshatološka nagrada.

Pošto se uvođenje Mevluda u praksu vezuje za četvrto stoljeće hidžre, nepobitna je istorijska činjenica da ga nisu prakticirali ni jedan od utemeljitelja mezheba (Malik, Ebu Hanife, Ahmed i Šafija), zatim, niti druga od sviju priznata ulema, Es-Sevri, El-Lejs, El-Evzai i mnogi 
drugi. Hafiz Es-Sehavi navodi u svojim Fetvama: Praksa Mevluda nije prenešena ni od jednog iz generacije pravovjernih (selefus-salih) iz prva tri najvrijednija stoljeća, nego se ta praksa desila, kasno, poslije toga. ${ }^{20}$

A Nesai (2719.) zabilježio je hadis koji eksplicitno govori o tome da Poslanik, a.s., nije ništa izostavio od vjere što bi bilo bitno, nije izostavio nešto što približava Uzvišenom ili zaboravio ili zanemario neku njegovu naredbu ili zabranu. Vjeru je dostavio kompletnom:

Allaha mi nisam vam izostavio ništa što vas može približiti Allahu $i$ džennetu a da vas nisam obavijestio o njemu, niti sam vam izostavio nešto što vam je Uzvišeni naredio a da vam to i sam nisam naredio, niti sam što izostavio što vam je Uzvišeni zabranio a da vam nisam to zabranio.

Es-Sejjid Rešid Rida, kao savremeni reformator islamske ideje i prakse, posebno se obrušio na nedozvoljene stvari koje prate mevludske svečanosti, smatrajući Mevlud novotarijom i slijeđenjem stranaca pa navodi u El-Menaru: Mevludi su pijace griješenja u kojima se postavljaju šatori za golotinju, mjesta za alcohol, ples, gdje se ljudi okupljaju da bi gledali razgolićene plesačice i druga mjesta razvrata... Neka pogledaju gledaoci do kojih granica su dospjeli muslimani ,blagoslovom' sufija i njihovom ideologijom slijepog slijeđenja bez upotrebe razuma, kao i njihovo neslijeđenje Šerijata, kada su svoje šejhove uzeli za božanstvo... Kur'an i sunnet ne poznaju ove novotarije nego su nam došle kao tradicija ili društvena bolest od drugih naroda, pa je naš narod vidjevši od njih ove proslave pomislio da ako to pođu prakticirati biće bolje cjenjeni kod njih, tako da je to vid uzimanja lažnih božanstava što je glavni razlog zaostajanja islamskog svijeta... ${ }^{21}$

Velika grupa uleme smatra da je obilježavanje i sjećanje na rođenje Muhammeda, a.s., nedozvoljena novotarija kao što su: šejhul-islam Ibni Tejmije, imam Eš-Šatibi, Ibnul-Hadždž El-Maliki, zatim savremena puritanska ulema kao Ibnul-Baz, Ibnu U'sejmin i mnogi drugi.

\footnotetext{
${ }^{20}$ Muhammed b. Jusuf Es-Salihi Eš-Šami, Subulul-huda ver-rešadi fi sireti hajrili'badi, Darul-kutubil-i'lmijjeti, Bejrut, 1414/1993., 1/439.

${ }^{21}$ Muhammed b. Rešid b. A'li Rida b. el-Husejni, Tefsirul-Kur'anil-kerim/TefsirulMenar, El-Hejetul-Masrijje el-a'mme lil-kitab, 1990., 2/74-76.
} 
Njihovi argumenti su:

- Organizovanje Mevluda liči na ono što rade kršćani koji praznikuju, sjećaju se i obilježavaju rođenje Isaa, a.s., a muslimanima je zabranjeno slijeđenje običaja drugih kao što je došlo u hadisu:

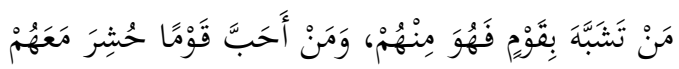

Onaj ko se poistovjeti sa nekim narodom on je od njih, a ko zavoli neki narod biće proživljen sa njima ${ }^{22}$

- Inovacija vremenskog blagdana kada će se ljudi okupljati radi ibadeta koji se smatra obaveznim ili dobrovoljnim, bez šerijatski valjanog argumenta, zabranjena je novotarija, jer Uzvišeni kaže:

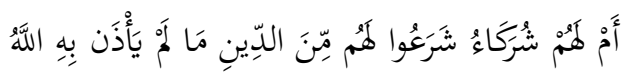

Zar oni da imaju bogove koji im propisuju da vjeruju ono što Allah nije naredio?! ${ }^{23}$

- Općepoznato je da obilježavanje i sjećanje na Mevlud nema osnovu u Kur'anu i sunnetu, nije to bilo u vrijeme Allahovog Poslanika, a.s., i u prva tri najvrijednija stoljeća islama, dakle novotarija Mevluda nije postojala u vrijeme ashaba, tabiina i tebiu't-tabiina, iako su selefus-salih (prve pravovjerne generacije), najviše voljeli Poslanika, a.s., bili njegovi najvjerniji i najgorljiviji sljedbenici. A Allahov Poslanik, a.s., kao što su zabilježili Buharija (2697.) i Muslim (1718.), rekao je, kao što prenosi Aiša, r.a.:

$$
\text { "مَنْ أَحْدَثَ فِي أَمْرِنَ هَذَا مَا لََسنَ مِنْهُ فَهُوَ رَدُّه" }
$$

Onaj ko uvede u našu vjeru ono što nije od nje, to mu se odbija. U verziji koju je zabilježio Muslim kaže se:

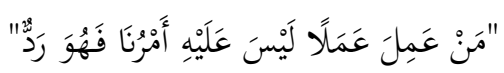

Ko bude prakticirao ono što nije naša vjera, to mu se odbija.

Ove dvije verzije hadisa zabranjuju uvođenje novotarije ili njeno prakticiranje, ako je već uvedena. Hadis je mjerilo za javna djela koja

\footnotetext{
22 Prvi dio hadisa bilježe: Ahmed u svome Musnedu (4868) i Ebu-Davud u svome Sunenu (Kitabul-libas, 3512.). Drugi dio hadisa zabilježio je Ebu-Abdullah el-Hakim, El-Mustedreku a'les-Sahihajni, Darul-ma'rife, 1418/1998, 3/556.

${ }^{23}$ Kur'an, Eš-Šura, 21.
} 
trebaju biti u skladu sa šerijatom. Ako to nisu, onda su novotarija koja se odbija u vjeri. Prema tome, iz hadisa se mogu izvući pravila:

1. Sve što ima uzrok u vremenu Poslanika, a.s., a on to nije prakticirao, obožavanje i vjerska praksa s time, vid je novotarije;

2. Zabrana nekog djela podrazumijeva da je to djelo pravno nevaljano, kao što je trgovina nakon drugog ezana za vrijeme džume;

3. Međutim, ako je zabrana nečega zbog nekih vanjskih opisa, a ne zbog samog zabranjenog djela, onda to ne podrazumijeva nevaljanost, kao onaj ko ukrade odjeću pa klanja u njoj. Krađa je zabranjena i to je nevaljani čin, ali je namaz valjan.

Prihvatanje novotarija uključuje optužbu Poslanika, a.s., da nije dostavio upotpunjenu vjeru, kao što kaže imam Malik, r.t.:

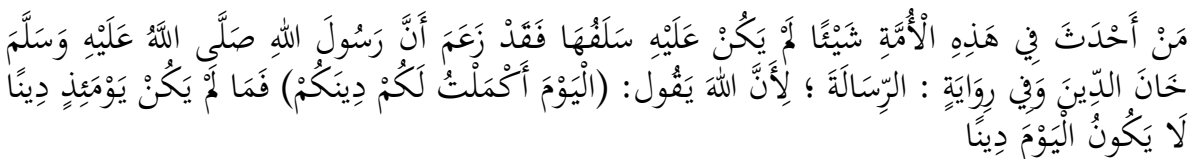

Ko inovira nešto u ovom ummetu na čemu nije bila generacija selefa, time tvrdi da je Allahov Poslanik, a.s., iznevjerio vjeru-u drugoj verziji se spominje: Misiju, jer je Uzvišeni obavijestio: Danas sam vam vašu vjeru usavršio..., prema tome što nije bilo tada vjerom ne može biti ni danas. $^{24}$

El-Fakihani koji je napisao knjigu El-Mevrid fi amelil-mevlid, navodi: Ne poznajem nikakav osnov za Mevlud u Kur'anu ili sunnetu. ${ }^{25}$

- Prvi koji su inovirali obilježavanje i proslavu Mevluda ili rođendana Poslanika, a.s., bili su pripadnici Benu U’bejda, ili El-U’bejdijuni, koji sebe nazivaju Fatimijama ${ }^{26}$, u četvrtom stoljeću hidžre.

\footnotetext{
${ }^{24}$ Ibrahim b. Musa Eš-Šatibi, Ebu Ishak, El-I'tisam, Mektebetut-tevhid, 1/49., 1/167. i $2 / 168$.

25 Tadžud-din el-Fakihani, El-Mevrid fi amelil-mevlid, str. 2.

26 Šejhul-islam Ibn Tejmije opisuje ih ,...najpokvarenijim i najvećim nevjernicima... Onaj ko ih smatra da su vjernici ili Božiji bogobojaznici, ili da im je to ispravna genealogija (porijeklo od Fatime, r.a.), govori o nečemu što ne zna (Medžmu'ulfetava, 35/127.).
} 
Što se tiče slijeđenja i oponašanja, Allahov Poslanik, a.s., najavio je da će se to dešavati u islamskom ummetu, pa je rekao:

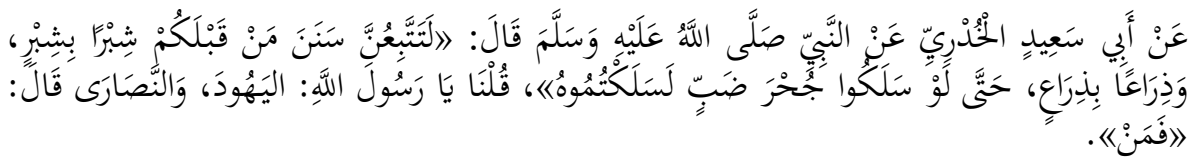

- Slijedićete puteve onih prije vas, pedalj po pedalj, lakat po lakat, pa čak da uđu u gušterovo sklonište, slijedili biste ih. Rekosmo: - Allahov Poslaniče, je li židove i kršćane? A on reče: - A koga drugog?!

- Mevlud, obilježavanje, praznikovanje i slavljenje rođendana Allahovog poslanika. a.s., vid je slijeđenja $i$ oponašanje slavljenja rođendana Isaa, a.s., koji se slavi u kršćanskom civilizacijskom miljeu, tako što su inovatori željeli tim činom da ukažu kako je Muhammed, a.s., preči za počast i slavljenje od Isaa, a.s.

\section{Istinska, prava novotarija (hakikije) i dodatna (idafije)}

Grupa uleme koja zabranjuje Mevlud dijeli novotariju na dvije vrste:

1. istinsku, pravu (hakikije) $\mathrm{i}$

2. dodatnu (idafije).

- Istinska, prava novotarija ,nema osnove niti dokaza za nju u Šerijatu, u njegovim izvorima: Kur'anu, sunnetu, idžmau, analogiji ili u nekoj drugoj vrsti dokaza koje priznaje ulema, generalno ili parcijalno, te se stoga i zove novotarijom, inovacijom koja nije bila prije."

- Dodatna, koja ima dvije vrste od kojih je prva vezana za dokaz, stoga u tom smislu i nije inovacija osim što je povezana sa nekom šerijatskom praksom, stopila se i pomiješala sa njom u većini slučajeva. Tako je volidba Poslanika, a.s., pravno valjana, kao i predavanje o siri Poslanika, a.s., učenje Kur'ana, donošenje salavata, zikr i vaz, međutim, kada se to pomiješa sa novotarijom u smislu uzimanja $i$ inoviranja određenog dana za slavljenje, koji se posebno odredi uprkos činjenici da ga Šerijat nije odredio, inovira se za tu priliku određeni ibadet, zikr i dove, onda ove inovacije u opisu ibadetske aktivnosti prevladaju; tako da dodatna postaje istinska, prava novotarija.

Pravnošerijatski ibadet izlazi iz okvira valjanosti na tri načina koji imaju zasebne, specifične propise: 
1. da ibadet bude izvan šerijatske valjanosti, tako da je to prava, istinska zabranjena novotarija,

2. da novotarija bude vezana za šerijatsku aktivnost i bude $u$ njenom opisu tako što se ne može odvojiti od nje, kao što je Mevlud, koji je u osnovi dodatna novotarija, ali kada se pomiješa sa drugim vidovima novotarskih opisa i aktivnosti koje prevladaju, onda i dodatna prelazi u pravu novotariju,

3. da se ibadet veže za šerijatsku aktivnost ali nije u njegovom opisu i ne uslovljava ga kao što je naglas nijetiti za namaz, to je dodatna novotarija, u čijem slučaju se prima valjani šerijatski ibadet, a ne prihvata inovacija i novotarija.

\section{Grupa koja dozvoljava obilježavanje Mevluda}

Obilježavanje i sjećanje na rođenje Muhammeda, a.s., dozvolila je grupa autoritativne uleme kao što su: Ibni Hadžer El-A'skalani, hafiz Es-Sujuti, hafiz Es-Sehavi, šejh Se'id Hava, šejh El-Karadavi i drugi. ${ }^{27}$

Onaj koji se spominje da je javno počeo slaviti rođenje Allahovog Poslanika, a.s., bio je sunnijski vladar o kojem imam Ez-Zehebi kaže u svom djelu Sijer e'alamin-nubela:

U Irbilu je bio pobožni, veličanstveni vladar, Muzaferud-din Ebu Se'id Kevkeberi b. A'li, b. Bektekin b. Muhammed Et-Turukmani... Bio je pružene ruke $i$ volio je da dijeli milostinju, dijelio bi na tovare kruha (hrane), oblačio preko godine svijet $i$ dijelio im dinar-dva, sagradio je četiri hanikaha za stare i bolesne osobe koje je lično posjećivao svakog ponedjeljka i četvrtka, pitajući svakog ponaosob o stanju $i$ zdravlju, dižući im moral $i$ šaleći se s njima... A bio je skroman $i$ dobroćudan, sunnijske provenijencije, volio je ulemu, fekihe i hadislije, a dijelio je izgleda i pjesnicima i nije preneseno da je u ratu izgubio. ${ }^{28}$

Slično ga opisuje i imam Ibnu Kesir, koji navodi u njegovoj biografiji: Bio je to jedan plemeniti, veličanstveni aristokrata, slavni vladar, koji

27 www.aljamaa.net/ar/document/65236.shtml, حكم الاحتفال بذكرى المولد النبوي - جماعة العدل والإحسان بقلم: عبد الله المومني (pristupljeno 06. januara, 2016.). Također, Džalaluddin EsSujuti, Odgovori, izbor fetvi, El-Kalem, Sarajevo, 1432-2011., str. 5-32.

${ }^{28}$ Džalaluddin Es-Sujuti, Odgovori, izbor fetvi, El-kalem, Sarajevo, 1432-2011., str. 14. 
je iza sebe ostavio lijepe tragove. On je uveo Mevlud u Rebiu'ul-evvelu, koji bi proslavio veličanstvenom proslavom i gozbom, a bio je pametan, energičan, oštrouman, hrabar, neustrašiv, pronicljiv, mudar, učen $i$ nadasve pravedan, Allah mu dao svako dobro i nagradu. ${ }^{29}$

Grupa islamske uleme iz sva četiri mezheba smatra dozvoljenim slavljenje rođendana najvećeg sina ljudskog roda i predvodnika čovječanstva, Muhammeda, a.s., i mnogi su napisali djela i radove na tu temu. Prvi koji je pisao i utemeljio Mevlud plemenitog Poslanika, a.s., je ekspert hadisa i fikha iz malikijskog mezheba hafiz Ebul-Hitab b. Dihje. O njemu je Ibni Hallikan napisao: Ebul-Hitab je bio jedan od vrhunske uleme i poznatih uglednika, ekspert nauke hadisa i znanosti vezanih za njega, poznavalac gramatike $i$ jezika, arapske istorije $i$ njenog pjesništva, bavio se hadiskom znanošću i prikupljanjem hadisa u većini Andaluzijskih islamskih zemalja susrećući se sa njihovim učenjacima $i$ šejhovima. ${ }^{30}$

Malikijski učenjak Muhammed b. Ebi Ishak b A'bbad En-Nefezi u svojoj knjizi navodi: (Mevlud je), kao što se pokazuje, blagdan muslimana, njihov praznik, $i$ sve što pretpostavlja radovanje $i$ veselje $u$ tom balgoslovljenom Mevludu od osvjetljenja i zadovoljenja očiju, pazeći na ono što se sluša i gleda, ukrašavanje oblačenjem lijepe odjeće, korištenje najljepših jahalica, sve je to dozvoljeno a ne pokuđeno, analogno drugim danima praznikovanja; a presuditi da se u tom vremenu upražnjavaju novotarije, kada se u tom vremenu pojavio onaj koji je Sirrul-vudžud (Tajna postojanja), i kada se ustoličio i'lmulu'hud (Znanost ugovora) zbog kojeg su se pogasile tame nevjerovanja i poricanja, prema tome to se kudi kod onoga ko to govori, jer to je mržnja i poricanje. Tvrdnja da ovo vrijeme nije šerijatski praznik za one koji imaju vjere, analogno Nejruzu i Mahredžanu, to je teška optužba od koje se gade zdrave ljudske duše, i odbijaju ih ispravni stavovi. $^{31}$

29 حكم الاحتفال بالمولد وفقاً لمذهب الإمام مالك www.awqaf.ae (pristupljeno 03. januara 2016.).

${ }^{30}$ Džalaluddin Es-Sujuti, Odgovori, izbor fetvi, El-kalem, Sarajevo, 1432-2011., str. 14.

31 Muhammed b Ebi Ishak en-Nefezi, Fetava Ehlu Ifrikija, vel-Endelus, vel-Magrib, $11 / 278$. 
I halife, vladari muslimana slavili su Mevlud Allahovog Poslanika, a.s., a sa njima su to radili mezhebske kadije (pravnici) iz sva četiri mezheba i sva poznata ulema. El-Makrizi u svojoj knjizi El-Mevai 'zu vel-i'tibar, navodi: Kada dođe vrijeme (Mevluda) podigne se ogromni šator, posjedne se sultan i sa njegove desne strane Šejhul-islam Siradžud-din, Omer b. Reslan b. Nasr El-Belkini, koji je bio šejh (učitelj) imama, hafiza hadisa Ibnu Hadžera, zatim sa lijeve strane šejh Muhammed b. Selame, Ebu Abdullah El-Magribi, zatim vrhovne kadije četiri mezheba, potom šejhovi uleme. Emiri (vladari) države sjedaju podalje od sultana, a kada karije izuče Kur'an, onda se podignu i učači ilahija i nešida, jedan po jedan, njih preko dvadeset, svakom se plati kesa sa 400 zlatnika, a svaki emir države ima svoju prostoriju u svili u kojoj se nakon akšam namaza prostiru bogate sofre na kojima se jede i uzima hrana, potom slijede sofre raznih slasnih slatkiša $i$ sl. ${ }^{32}$

\section{Ulema koja je dozvolila da se obilježava Mevlud:}

1. Imam hadisa, fekih Ebu Šame, učitelj (šejh) imama En-Nevevija. On je naveo u svojoj Risali: Najljepše što se inoviralo u našem vremenu je praksa koja se obnavlja svake godine na dan rođenja Poslanika, a.s., od dijelenja milostinje, činjenja dobrih djela, pokazivanje radosti $i$ ukrašavanje, što je znak volidbe $i$ ljubavi prema Poslaniku, a.s. $i$ njegovo srčano poštivanje kao znak zahvale Uzvišenom koji nam je podario njega kao vrijednost $i$ milost svjetovima. ${ }^{33}$

2. Imam i šejhul-islam Ibni Hadžer El-Askalani je na pitanje o Mevludu rekao slijedeće: U osnovi Mevlud je novotarija, ne prenosi se od prva tri stoljeća pravovjernih generacija, od ashaba, tabiina $i$ tabi'uttabiina, međutim, uprkos toga ovaj čin ima i lijepe stvari i suprotno od toga. Zbog toga, ako neko traga za tim lijepim stvarima u ovome, a kloni se njihove suprotnosti, onda će to biti lijepa novotarija, inače $n e^{34}$

3. Imam, hafiz, muhaddis Dželalud-din Es-Sjuti. O pitanju Mevluda, novotarijama, vrsti novotarija i sl., navodi opširno što se može naći i u

\footnotetext{
32 www.awqaf.ae (pristupljeno 03. januar 2016.).

${ }^{33}$ Ibid.

${ }^{34}$ Ibid.
} 
prijevodu njegovih Odgovora i izbora fetvi koju je na bosanskom jeziku izdao El-Kalem. On vidi novotariju $d a$ se dijeli na pohvaljene $i$ pokuđene, zatim citira imama Šafiju koji je rekao: Dvije su vrste novotarije: pohvaljena i pokuđena. Ono što se slaže sa sunnetom, to je pohvaljena, a ono što se suprostavlja sunnetu, to je pokuđeno." Potom je naveo hazreti Omerov slučaj. Imami Šafija je također, rekao: "Dvije su vrste novotarija. Jedna je koja je oprečna knjizi ili sunnetu, eseru ili idžmau'u - ta je novotarija zabluda. A druga novotarija je ona koja je inovirala neko dobro i nije oprečna spomenutim izvorima - to je nepokuđena novotarija. A već je Omer za zajedničko klanjanje teravihnamaza tokom mjeseca ramazana kazao: ,Divna je ovo novotarija!'što znači da nije postojala ranije. ${ }^{35}$

O lijepoj novotariji (bid'a hasena) kaže: Postoji opća saglasnost oko toga da je lijepa novotarija (bid'a hasena) dozvoljena i preporučena novotarija, jer se za onoga ko je u njoj imao plemenitu namjeru čak predviđa nagrada. To su zapravo novine $i$ novotarije koje su $u$ saglasnosti sa šerijatskim pravilima $i$ koje ni u čemu ne oponiraju Šerijatu kao što su: gradnja munara, karaula, medresa, hanova na putevima i drugih dobrotvornih ustanova koje nisu postojale u početku islama. $^{36}$

Prezrenu novotariju (bid'a mezmuma) definira kao: oprečnu Šerijatu... a dijeli se na zabranjenu (bid'a muharrema) $i$ pokuđenu (bid'a mekruha). Potom spominje i novotarije koje vode u propast a to je novotarija $u$ vjerovanju (akida)... ${ }^{37}$

Nakon što je objasnio i definirao vrste novotarija on navodi za Mevlud: Osnova obilježavanja Mevluda, koja se sastoji u okupljanju muslimana, učenju Kur'ana, recitiranju veličanstvenih događaja $u$ vezi $s$ Vjerovjesnikovim, a.s., dolaskom na ovaj svijet te postavljanju sofre, ne pridodavajući spomenutom ništa što je pokuđeno, jeste jedan od lijepih običaja za koje će onaj ko ga bude prkticirao biti nagrađen, jer se takvim obilježavanjem Mevluda iskazuje poštovanje prema

\footnotetext{
${ }^{35}$ Džalaluddin Es-Sujuti, Odgovori, izbor fetvi, El-kalem, Sarajevo, 1432-2011., str. 6.

${ }^{36}$ Džalaluddin Es-Sujuti, Odgovori, izbor fetvi, El-kalem, Sarajevo, 1432-2011., str. 7.

37 Ibid. 8-9.
} 
Vjerovjesniku, a.s., pokazuje radost i sreća zbog njegovog, a.s., rođenja. ${ }^{38}$

4. Imam hafiz Ebul-Hajr Es-Sehavi, koji je naveo u svojim Fetvama:

Prakticiranje plemenitog, časnog Mevluda nije preneseno od pravovjernih prijašnjih generacija iz prva tri stoljeća, to se desilo poslije toga, nakon čega su muslimani u različitim dijelovima islamskog ummeta i velikim gradovima praznikovali u mjesecu rođenja Poslanika, a.s., praveći velike, raskošne svečanosti utemeljene na visokoj luksuznoj razini, dijeleći različite vidove milostinje u njegovim noćima, iskazujući radost i povećane vidove dobročinstva, držeći se učenja Mevluda dok se na njima mogao primijetiti uticaj njegovog blagoslova. ${ }^{39}$

5. Imam Ěššihab Ahmed El-Kastelani, komentator Buharije, koji navodi u svojoj knjizi: Da Uzvišeni nagradi vladare koji su stavili u običaj da se slave noći njegovog blagoslovljenog rođenja... ${ }^{40}$

6. Veliki učenjak i šejh iz šafijskog mezheba, Muhammed b. Omer ElHadremi koji navodi u svojoj knjizi: Dan kada je na svijet došao Mustafa, s.a.v.s., zaslužuje da bude uzet kao praznik. ${ }^{41}$

7. Imam i veliki šafijski alim Sadrud-din Mevhub b. Omer El-Džezeri koji je izjavio: Mevlud je novotarija koja ne smeta. Nisu pokuđene novotarije osim ako su u suprotnosti sa sunnetom... Čovjek će biti nagraden u skladu sa svojim ciljem, nijetom ako je pokazivao radost $i$ veselje zbog rođenja Vjerovjesnika, a.s. ${ }^{42}$

Primjedbe, argumenti i dokazi onih koji zabranjuju slavljenje Mevluda:

1. Tvrdnja: Mevlud su prvi uveli i izmislili šiije, Fatimije. Čak i u slučaju da je ova primjedba tačna, to nije argument za zabranu, posebno jer se zna da je Allahov Poslanik, a.s., preuzeo od židova i uzeo postiti

\footnotetext{
${ }^{38}$ Ibid. 13-14.
}

39 حكم الاحتفال بالمولد وفقاً لمذهب الإمام مالك. www.awqaf.ae (pristupljeno 03. januar 2016.).

40 Ahmed b. Muhammed el-Kastelani, El-Mevahibul-ledunijje bil-minehilMuhammedijje, El-Mektebul-islami, 1425/2004., 1/148.

حكم الاحتفال بالمولد وفقاً ملذهب الإمام مالك. www.awqaf.ae (pristupljeno 03. januar 2016.) 42 Ibid. 
dan Musaove, a.s., pobjede koju su židovi slavili, izrekavši poznati hadis koji je zabilježio Buharija:

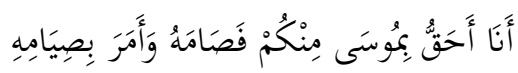

- Ja sam preči Musau od vas. Taj dan je postio i naredio da se posti.

2. Zabrana Mevluda pod kvalifikacijom da je to novotarija. Allahov Poslanik, a.s., rekao je, kao što je zabilježio Muslim:

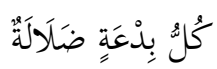

Svaka ${ }^{43}$ novotarija je zabluda.

\section{Vrste dozvoljenih i zabranjenih (zabluda) novotarija}

Kod ove grupe novotarija se dijeli na dvije vrste: lijepa i ružna, što zastupa grupa islamske uleme. Između ostalih i imam Šafija kojega smo već citirali a koji je rekao: Novotarije su dvije vrste: ona koja je u koliziji sa Kur'anom, sunnetom, predajom, konsezusom; i ta je zabluda. Druga vrsta novotarije je ono što se inovira kao vid hajra-dobra, i niko to ne drži pokuđenom novotarijom. Ebu Šame, koji u svom vremenu nije imao premca u znanju, moralu i pobožnosti-vjeri, bio je ekspert u Šerijatu za kojega drže da je postigao stepen vrhunskog pravnog eksperta (mudžtehid), odnosno da može samostalno derivirati i donositi propise iz šerijatskih izvora, i on kaže: Prema tome, lijepa novotarija je prihvaćena konsezusom kao dozvoljena i pohvaljena praksa za koju se očekuje nagrada onome ko uljepša svoj nijet u njoj, a to je svaka inovacija koja je u skladu sa pravilima Śerijata, ako nije u sukobu sa njima, ili ako njeno prakticiranje ne prouzrokuje nešto što je šerijatski zabranjeno.

Imam i šejhul-islam El-I'zz b. A'bdus-Selam, koji slovi kao Sultan uleme, novotariju dijeli na: novotariju prakse koja nije bila u vrijeme Poslanika, a.s., i dalje, na novotariju: obaveze, zabranjenu, lijepu,

${ }^{43}$ Svaka novotarija, (كُلْ بِنْعَة) znači, većina novotarija, kao što komentariše i EnNevevi kod Komentara Muslimovog Sahiha. Dakaz za to je i ajet:

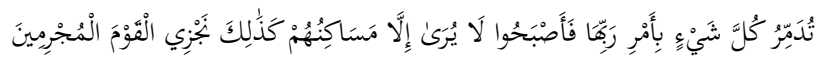

"Koji, voljom Gospodara svoga, sve ruši. I ujutro su se vidjele samo nastambe njihove; tako Mi kažnjavamo narod grješni (Kur'an, El-Ahkaf, 25.). Dakle, u ajetu se vidi da nije sve porušeno, jer su ostale nastambe njihove... 
pokuđenu i dozvoljenu. Novotarija se prepoznaje i cijeni tako što se usporedi sa šerijatskim pravilima, pa ako je unutar onih koja su obavezna, onda je obavezna, ili ako je unutar zabranjenih, zabranjena je, ili unutar lijepih, lijepa je, ili pokuđenih, pa je pokuđena, ili dozvoljenih pa je dozvoljena. ${ }^{44}$

3. Nijekanje postojanja dokaza za vrednovanje dana rođenja Muhammeda, a.s. Allahov Poslanik, a.s., kao što je zabilježio Muslim, pitan je o postu ponedjeljkom, pa je rekao:

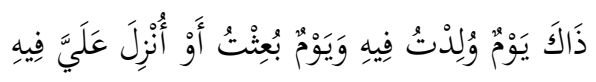

To je dan kada sam rođen, kada sam poslan ili kada mi je objavljeno...; pa je i sam veličao taj dan rođenja s postom. Veličanje i poštivanje odabranih dana je potvrđeno Šerijatom, tako je Poslanik, a.s., postio i dan Ašure i naređivao da se posti.

4. Zabrana obilježavanja Mevluda pod izgovorom činjenja prijestupa u tom praznikovanju. Naravno ovo nije argument zabrane Mevluda jer se mogu zabraniti zabranjene stvari u obilježavanju, a one koje su korisne i pohvalne prakticirati.

5. Zabrana obilježavanja Mevluda zbog činjenice da je to i dan njegove smrti. Ovo nije argument kao što je naveo i Sujuti, jer je u Šerijatu pravilo da se zahvali na blagodati a da se na nesreći strpi. Prema tome, ovom prigodom se izražavaju vidovi radosti i veselja povodom rođenja Muhammeda, a.s., Vjerovjesnika Milosti svjetovima.

6. Zabrana obilježavanja Mevluda zbog činjenice da ga nisu obilježavale prijašnje pravovjerne generacije ashaba, tabiina $i$ tabiu't-tabiina. Na tu primjedbu odgovaraju sa stavovima Šafije, Ibni Hadžera, Ebu Šame, El-Džezerija i drugih.

\section{Šerijatska i jezička novotarija}

Iz mišljenja već spomenute uleme vidljivo je da se novotarija dijeli na lijepu i ružnu/pokuđenu, tako da ono što ima temelj i osnov u Šerijatu, ne računa se novotarijom. A obilježavanje Mevluda oslanja se na temelje Šerijata, koji su ranije navedeni, pa prema tome nije novotarija, makar po tome ne postoji praksa prvih pravovjernih generacija. $\mathrm{U}$ tu

سكم الاحتفال بلمولد وفقاً مذهب الإمام مالك www.awqaf.ae (pristupljeno 03. januar 2016.). 
svrhu navode i riječi Kurtubija, imama komentatora Kur'ana koji u svom djelu Ahkjamul-Kur'an navodi:

Svaka novotarija koju uvede neko, mora imati šerijatski temelj ili ne. Ako ima temelj, onda potpada pod općenitost koju je Uzvišeni Allah učinio lijepom i stimulisao Svoga Poslanika, a.s., da to prakticira pa ulazi u okvir pohvalnog. A ako je novotarija u kontradikciji sa onim što je Uzvišeni naredio i Njegov Poslanik, a.s., onda to ulazi u okvir onoga što se zabranjuje i kudi... U tom smislu su riječi Poslanika, a.s., u hutbi: ... a najgore su stvari novotarije, a svaka (većina) novotarija je zabluda, tako da sa tim želi i cilja na ono što nije u skladu sa Kur'anom $i$ sunnetom ili sa praksom ashaba, r.a. ${ }^{45}$

Kaže imam Ibni Kesir: Novotarija ima dvije vrste: šerijatska, kao što se spominje u riječima Poslanika, a.s.: - Svaka inovacija je novotarija, a svaka (mnoga) inovacija je zabluda; i jezička novotarija kao što su riječi halife Omera b. El-Hattaba, kada je prijatno iznenađen sa ogromnim brojem ashaba na teraviji rekao: - Divne li novotarije! ${ }^{46}$

Imam Ibnu Redžeb, navodi: Pod novotarijom se misli na ono što se uvede $i$ inovira a nema osnove u Šerijatu koja bi na to upućivala, međutim, ono što ima osnovu u Šerijatu koja na nju upućuje, nije novotarija pravno, makar bila novotarija jezički. ${ }^{47}$

\section{Razlika između novotarije, javne koristi i istihsana}

Imam Šatibi koji je utemeljitelj teorije intencija i ciljeva koji se hoće postići sa prakticiranjem šerijatskih propisa, navodi:

Ovo poglavlje obavezuje na to da se odredi i definira novotarija, i ono što nije, jer mnogo ljudi ubraja većinu javnih koristi u novotarije, to vezuju za ashabe i tabiine uzimajući kao dokaz za ono što inoviraju od obredoslovlja; $i$ drugi koji su novotarije podijelili na vrste šerijatskih propisa, pa su: obavezne (vadžib) i pohvalne (mendub). U obavezne ubrajaju knjige mushafa, a u pohvalne okupljanje u džemat kod jednog karije... Lijepe novotarije u vjeri se vraćaju na osnov koristi, po tvrdnji

\footnotetext{
${ }^{45}$ Tefsirul-Kurtubi, 2-87.

${ }^{46}$ Ibn Kesir, Tefsir, 1-162.

${ }^{47}$ Ibnu Redžeb, Ebul-Ferdž, Džamiu'l-u'lumi vel-hikemi fi šerhi hamsine hadisen min dževamii’l-kelimi, Daru Ibni Kesir, 1429/2008., 1/266.
} 
onih koji ih uvode u Šerijat, pa ako se ovo potvrdi, i ako se istinski uzme u obzir javna korist, onda se istinski uzima u obzir i lijepa novotarija, $i$ obratno, jer dolaze iz istog osnova... Međutim, javna korist nije novotarija... I smatramo da odgovarajuće značenje s kojim se vezuje propis ne izlazi iz okvira:

1. da Šerijat to prihvata, kada ne postoji problem valjanosti niti razlaz u njegovoj praksi, inače je suprotno Šerijatu, kao što su fiksirane kazne taliona da bi se postigla korist čuvanja života,

2. da Šerijat to odbija, onda ne postoji način da se to prihvati... Nego, kada se pojavi neko značenje i razumijemo da ga Šerijat uzima u obzir, tada ga prihvatamo,

3. sa korišću se hoće, kod nas, ono što žele adresati Šerijata od priskrbljivanja koristi $i$ otklanjanja štete na način da to čisti razum-pamet samostalno ne prosuđuje $i$ razumijeva, ni u kom slučaju, a ako Šerijat ne uzima u obzir određeno značenje ili ga odbacuje, onda se to odbija po konsezusu muslimana. ${ }^{48}$

Za imama Malika, utemeljitelja malikijskog mezheba, prenosi se da iz poštovanja prema Allahovom Poslaniku, a.s., u Medini nije jahao životinju. Ovo je inovacija imama Malika, koju niko drugi nije prakticirao, čak ni od ashaba koji su najviše voljeli i cijenili Muhammeda, a.s. Međutim, ovu inovaciju niko od poznate uleme nije pokudio. Malikijski imam Kadija Ijad u svom djelu Ěs-Šifa' navodi: Malik, Allah mu se smilovao nije u Medini jahao životinju, govoreći: Stid me je Allaha, da po zemlji u kojoj je Allahov Poslanik, a.s., hodaju životinjska kopita-papci. ${ }^{49}$.

Obrazloženje onih koji su dozvolili Mevlud ${ }^{50}$ :

1. Ostavljanje Poslanika, a.s., nečeg ne upućuje na nedozvoljenost, a Poslanik, a.s., je izostavljao mendube (lijep, pohvalan) i mubahate (dozvoljenosti), prema tome, njegovo izostavljanje toga ne upućuje da

\footnotetext{
${ }^{48}$ Ibrahim b. Musa eš-Šatibi, Ebu Ishak, El-I'tisam, Mektebetut-Tevhid, 2/111-113.

49 1/275. Isto ovo je zabilježio i hanefijski pravnik, Kemalud-din Ibnul-Humam u svome djelu Fethul-Kadir, 3/180., i Ibnul-A'rebi El-Maliki u djelu Ahkamul-Kur'an, $3 / 254$.

50 www.aljamaa.net/ar/document/65236.shtml, حكم الاحتفال بذكرى المولد النبوي - جماعة العدل والإحسان بقلم: عبد الله المومني (pristupljeno 06. januara, 2016.).
} 
je to zabranjeno. Ovaj stav potvrđuje i predaja koju su zabilježili Buharija (1337.) i Muslim (7288.) da je Allahov Poslanik, a.s., rekao:

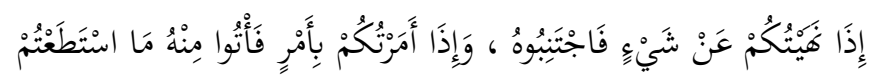

Kada vam zabranim nešto, ostavite to $i$ ne činite ga, a kada vam naredim nešto, izvršite ga u mjeri koliko ste u mogućnosti. Prema tome u hadisu nije spomenuto ako nešto ostavim, ostavite ga..., tako da je to dokaz da ono što je Poslanik, a.s., izostavio ostaje u svom prirodnom stanju dozvoljenosti, jer kad bi rekli o zabranjenosti svega što je ostavio Poslanik, a.s., onda bi suzili krug dozvoljenosti a proširili krug zabrane, što bi dovelo do teškoće u vjeri koju je Uzvišeni otklonio od ove vjere koja se opisuje da je vjera olakšica i olakšavanja adresatima.

Isto tako, to što su ashabi ostavili i nisu obilježavali Mevlud nije dokaz zabrane jer su živjeli sa Allahovim Poslanikom i bili u stalnoj živoj komunikaciji i vezi sa njim i bez takvih mevludskih prigoda, kao što to navodi šejh Jusuf El-Karadavi: Oni su živjeli sa Poslanikom, a.s., on je živio u njihovim osjećajima, njihovim svijestima, tako da je Sa'd b. Ebi Vekkas prenio: - Kazivali smo i prenosili djeci o bitkama koje je vodio Allahov Poslanik, a.s., kao što smo ih učili suru iz Kur'ana, da i oni prenose svojim potomcima šta se dešavalo u bici Bedra, Uhuda, Handeka, Hajbera; tako da su i oni prenosili šta se dešavalo u životu Poslanika, a.s., pa nisu bili u potrebi za Mevludom. ${ }^{51}$

Isto tako možemo kazati i za ostavljanje selefus-saliha, prvih pravovjernih generacija, obilježavanje i sjećanje na Mevlud, da nije bilo povezano sa nedozvoljenosti tog čina ili njegovom pokuđenosti, tako da u krajnjoj konsekvenci može se kazati samo da oni to nisu činili.

2. Što se tiče tvrdnje da je obilježavanje Mevluda novotarija koja vodi u propast i zabludu, jasno je da se pod tim misli na inovaciju i novotariju koja nema nikakvu osnovu u vjeri i njegovom sistemu Šerijata, ili da je to vid vjerske prakse koja nije u skladu sa sunnetom Allahovog Poslanika, a.s. Međutim, obilježavanje Mevluda nije to. Imam EsSujuti navodi da je to lijepa novotarija za koju se ima nagrada zbog veličanja Allahovog Poslanika, a.s., i izržavanja radosti i zadovoljstva rođenjem Plemenitog Poslanika, a.s. Može se nazvati izrazom ,sunne

\footnotetext{
${ }^{51} \mathrm{http}$ //www.qaradawi.net/site/topics/article.asp?cu_no $=2 \&$ item_no $=5852 \&$ version $=1 \&$ template_id=130\&parent_id=17 (pristupljeno 06. januar, 2016.).
} 
hasene" (lijep običaj/sunnet) kao što je došlo u vjerodostojnom hadisu kojeg je zabilježio Muslim (1017.):

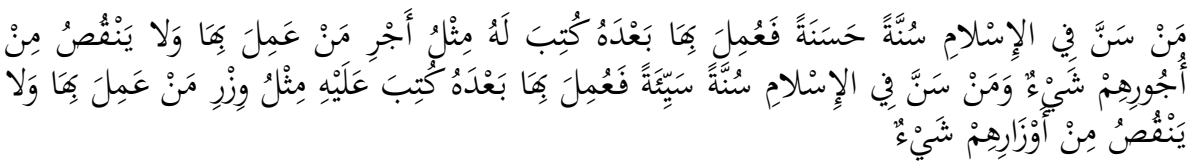

Ko uvede u vjeru lijep običaj pa se to bude prakticiralo nakon njega, biće mu upisana nagrada kao i onome ko to bude prakticirao, bez da se njima išta oduzme od njihove nagrade, a ko uvede u vjeru ružan običaj, pa se to bude prakticiralo nakon njega, biće mu upisan teret kao $i$ onome ko to bude prakticirao, bez da se njima išta oduzme od njihove kazne.

Ashabi kao i četverica pravednih halifa su uveli i inovirali neke aktivnosti koje nisu bile prije, ali to nije bio ni predmet spora kada su uvedene, kao što je klanjanje teravije u džematu i reakcija Omera, r.a., kada to naziva divnom novotarijom. Kodifikacija Kur'ana i njegovo zapisivanje na jednom harfu Zejd b. Sabit je okarakterisao kao obavezu koja mu je teže pala nego da su mu naredili da prenese brdo iz razloga što to Allahov Poslanik, a.s., nije uradio za svoga života itd. Ali to je urađeno i prihvaćeno kao korisno konsezusom! Gradnja munara, inoviranje novih vjerskih znanosti (usuli fikh, nauka džerha i ta'dila i sl.) i pisanje knjiga na tu tematiku, isto tako je vid lijepe novotarije itd.

3. Obilježavanje Mevluda i sjećanje na rođenje Poslanika, a.s., nije vjerski obred, koji je Uzvišeni Allah naredio, nego je vid običaja i u'rfa kojeg su ustalili i uveli ljudi, a Šerijat ga je potvrdio kao dozvoljen, ako se u njemu ne pojavljuju zabranjene stvari i nedozvoljenosti, ili ga zabranjuje ako je utemeljen na haramu i nedozvoljenostima. A pošto je obilježavanje i sjećanje na Mevlud u osnovi podsjećanje na biografiju Allahovog Poslanika, a.s., i njegov moral, onda je to dozvoljeno i može se za to očekivati i nagrada.

4. Dokaz za dozvolu obilježavanja Mevluda i sjećanja na rođenje Poslanika, a.s., je i stav kako je po ovom pitanju postignut konsezus u vrijeme prvog Mevluda u IV stoljeću, a ne prenosi se protivljenje uleme sve do VII stoljeća. Prenose se vijesti i o prisustvovanju toj proslavi velikog broja pravnika, uleme, što znači da su to podržali. Ibnu Hallikan spominje gozbu Mevluda i navodi: Stanovnici susjednih pokrajina Irbilu, čuli su za mišljenja njihovog vladara o Mevludu kao lijepom 
činu, tako da su svake godine dolazile na proslavu Mevluda brojne grupe pravnika, uleme, sufija, vaiza, karija i pjesnika, iz Irbilu bližih zemalja i metropola kao što su Bagdad, Mosul, Džezira, Sindžar, Nusajjibin i drugih stranih, nearapskih zemalja i strana. ${ }^{52}$

Nakon svega oni koji dozvoljavaju Mevlud smatraju da bi se moglo zaključiti slijedeće: Ako obilježavanje i proslava Mevluda ne bude prožeta sa nedozvoljenim radnjama i pojavama, onda nema zapreke za njegovo održavanje. Naprotiv, postoje mnogobrojne koristi koje čine organizatore Mevluda da na takav način oživljavaju ono što se zaboravi od sunneta Allahovog Poslanika, a.s., njegove biografije i njegove sire, da se donesu salavati na njega, a.s., obnove njegove pohvale i izrazi zahvala na veličanstvenoj blagodati i milosti poslanoj svjetovima u liku Pečata Poslanstva i Milosti svjetovima. Prema tome, nema zapreke da se mjesec Mevluda učini mjesecem u kojem se nanovo iskažu emocije i ljubav prema Poslaniku, a.s., ili govori i propagira bilo koji aspekt njegove Misije sa kojom je došao kao Milost svjetovima.

\section{Stav Ibni Tejmije o Mevludu}

Pošto su za šejhul-islama Ibni Tejmiju rekli da je u grupi onih koji dozvoljavaju Mevlud, uputno je, zbog njegovih posebno interesantnih i originalnih stavova o Mevludu da ih spomenemo i osvrnemo se na njih, makar radi intelektualne istine. Iz analize njegovih kompletnih stavova i mišljenja o ovoj temi proizilazi kategoričan stav da je Mevlud vid novotarije. Izlažući svoj stav o pitanju slavljenja rođendana Poslanika, a.s., on kaže u svojoj knjizi Iktidaus-siratil-mustekimi limuhalefeti ashabil-džehim:

Činjenica je da ovo nije prakticirala generacija selefa (pravovjerni prethodnici), uz mogućost da to čine i nepostojanja zapreke, da je $u$ tome bilo neko dobro. A da je ovaj čin bio čisto, istinsko dobro i hajr, ili makar, da je prevladavao stav kako je to dobro, onda je sigurno da bi ove generacije bile preče od nas, da to praktikuju, jer su gajili mnogo snažniju ljubav i poštovanje prema njemu od nas, i bili su spremniji nego mi na činjenje svakog vida dobra. Potpuna ljubav prema njemu $i$ njegovo poštovanje manifestuje se u njegovom slijeđenju, pokornosti $i$

${ }^{52}$ Ahmed b. Muhammed b. Ebi-Bekr b. Hallikan, Vefejatul-ea'jan ve ebnau ebnaizzeman, Daru Sadir - Bejrut, 1972., 5-117. 
potčinjavanju njegovoj naredbi, oživljavanju njegovog sunneta, tajno $i$ javno, prenošenju i obznanjivanju njegove Misije sa kojom je poslan, borbi za sve to, srcem, rječju $i$ djelom. To je bio metod $i$ put prvih generacija, muhadžira i ensarija $i$ onih koji su ih slijedili. ${ }^{53}$

Isto tako, u svojim Fetvama, Ibni Tejmije, dotičući se ovoga pitanja, eksplicitno tvrdi da je Mevlud novotarija:

Ustrojavanje praznika, osim šerijatskih, kao što su neke noći, primjerice u mjesecu Rebiu'l-evvelu, noć za koju se tvrdi da je noć Mevluda, ili neke noći mjeseca Redžepa, ili osamnaesti dan Zulhidždžeta, ili Prva džuma u Redžepu, ili osmi dan Ševvala kojeg neznalice prozvaše „Praznikom dobročinitelja”, sve su to novotarije koje nisu poštovale pravovjerne generacije selefa, niti su to prakticirali, a Uzvišeni Allah najbolje zna. ${ }^{54}$

Međutim, i pored ovog jasnog eksplicitnog stava Ibni Tejmije, neki autori, želeći da opravdaju svoj stav o ispravnosti mevludskog praznikovanja, svrstavaju ga u grupu onih koji dozvoljavaju Mevlud i ne smatraju ga novotarijom, navodeći njegov stav iz kojeg je vidljivo da su ga očito htjeli pogrešno interpretirati, jer je potpuno jasan i razumljiv, i ne daje povoda spekulaciji o tome da je Mevlud novotarija. Naime, Ibni Tejmije, navodi u ranije spomenutom izvoru, neposredno prije navedenog citata slijedeće stavove koje su neki htjeli interpretirati svojim argumentom za dozvolu Mevluda:

Uzimanje ovoga dana praznikom je novotarija koja nema nikakvu osnovu, jer u generaciji pravovjernog selefa niko, pa ni Poslanikova porodica, nije slavila taj dan u kojem bi inovirali neke aktivnosti, jer su slavljenja vid Šerijata koji se obavezno slijedi, a ne da se inovira. Allahov Poslanik, a.s., imao je hutbe, mirovne ugovore, bitne situacije u raznim danima kao što je Dan Bedra, Hunejna, Handeka, Osvojenje Mekke, Hidžra, Preseljenje u Medinu, predavanja u kojima je objašnjavao temelje vjere. Međutim, sve to nije uslovilo da se ovi događaji uzmu kao praznici. Kršćani su uzeli događaje iz života Isaa,

\footnotetext{
${ }^{53}$ Ibn Tejmije, Iktidaus-siratil-mustekimi limuhalefeti ashabil-džehim, bitahkik Nasir A'bdul-Kerim, Daru A'lemil-kutub- Bejrut, sedmo izdanje, 1419. h. (1999. m.), $2 / 123$.

${ }^{54}$ Ibni Tejmije, Medžmu’ul-fetava, 25, 298.
} 
a.s., praznicima, $i$ židovi takođe, međutim, praznik je ono što Šerijat kaže da je praznik, odnosno, ono što Uzvišeni Allah uzakoni to se doktrinarno slijedi. U vjeru se ne uvodi ono što nije vjera. Niti ono što inoviraju ljudi kao novotariju, koja je trebala da bude nasuprot kršćanskog praznikovanja za rođendan Isaa, a.s., ili kao ljubav $\boldsymbol{i}$ poštovanje prema Poslaniku, a.s., za koje će ih Uzvišeni Allah možda nagraditi zbog njihove ljubavi i njihovog idžtihada, ne za novotarijuone koji su uzeli rođendan Poslanika, a.s., za praznikovanje uprkos njihovog sporenja oko dana rođenja - pa doista činjenica je da ovo nije prakticirala generacija selefa (pravovjernih prethodnika), uz mogućost da to čine i nepostojanja zapreke, da je u tome bilo neko dobro. A da je ovaj čin bio čisto, istinsko dobro i hajr, ili makar, da je prevladavao stav kako je to dobro, onda je sigurno da bi ove generacije bile preče od nas da to praktikuju, jer su više od nas gajili snažnu ljubav $i$ poštovanje prema njemu, i bili mnogo spremniji nego mi na činjenje svakog dobra. Potpuna ljubav prema njemu $i$ njegovo poštovanje manifestuje se u njegovom slijeđenju, pokornosti $i$ potčinjavanju njegovoj naredbi, oživljavanju njegovog sunneta, tajno $i$ javno, prenošenju i obznanjivanju njegove Misije sa kojom je poslan; borbi za sve to, srcem, rječju i djelom. To je bio metod i put prvih generacija, muhadžira i ensarija $i$ onih koji su ih u tome slijedili ... ${ }^{55}$

A zatim je dodao:

A većinu njih vidiš da su revno prihvatili ovu novotariju, uz to što imaju lijep nijjet i idžtihad za koje se nadamo da će imati nagradu. Uz sve to vidiš ih da su popustili u odnosu na Poslanikovu naredbu i obavezu onoga što im je naređeno da čine, tako da su na stepenu primjera onoga ko voli mushaf, međutim ostavi ga i ne uči u njemu, ili uči ali ne slijedi, ili na stepenu i primjeru onoga ko kiti mesdžid, ali ne klanja u njemu, ili klanja rijetko. ${ }^{56}$

Isto tako njegove su riječi:

Neki ljudi poštuju Mevlud i uzimaju ga praznikom, i imaće za to veliku nagradu zbog lijepog nijeta $i$ zbog poštivanja ličnosti Allahovog

\footnotetext{
55 Ibn Tejmije, Iktidaus-siratil-mustekimi limuhalefeti ashabil-džehim, Dar A'lemilkutub, Bejrut, sedmo izdanje, 1419. h. (1999. m.), 2/123.

56 Ibid.
} 
Poslanika, a.s., kao što sam ti već naveo, naime, nešto može biti lijepo ako je urađeno od nekih ljudi, dok je isto to djelo, urađeno od pravog vjernika, ružno. Tako su se požalili imamu Ahmedu na nekog vladara primjedbom: - On je potrošio na ukrašavanje Mushafa 1000 dinara! Ili nešto slično tome. A imam Ahmed je rekao: - Pusti ga. To je najvrijednije u što mogu potrošiti svoje zlatnike...Uz primjedbu da je stav imama Ahmeda o ukrašavanju Mushafa pokuđenost (mekruh). U konkretnom slučaju cilj imama Ahmeda bio je ukazati u ovom primjeru na to da ima neka korist, uz postojanje nečeg zbog čega je to $i$ pokuđeno. Međutim, ova vrsta ljudi da nije uradila ovo u čemu postoji dobro i pokuđenost, onda bi možda uradila nešto gore (i u čemu nema hajra), kao da potroše tu svotu na romane $i$ bizantijsko perzijsku poeziju ${ }^{57}$.

Ibni Tejmije je rekao i ovo:

Čovjek može da uradi neko djelo smatrajući ga ispravnim, a ne zna da je to zabranjeno, tako da bude nagrađen za lijep nijet $i$ oprosti mu se zbog neznanja. Ovo područje je jako obimno i široko. Općenito, novotarski vid ibadeta je zabranjen, ali ga ljudi praktikuju i od toga ima neke koristi, ali to ne upućuje da je to djelo valjano... Onaj ko to praktikuje može to pogrešno tumačiti, pogriješiti kao mudžtehid ili sljedbenik, tako da mu se oprašta greška i nagrađuje za svoje dobro pravno valjano djelo, koje je vezano i sa onim što nije valjano, kao slučaj mudžtehida koji pogriješi ${ }^{58}$

Ibni Tejmije navodi da djela imaju stepene, tako da djelo čija se vrijednost vraća samo čistom, lijepom nijetu bio je metod prvih pravovjernih generacija selefus-saliha, međutim današnja realnost mnogih vjernika koji su time iskušani nije u skladu s tim, za razliku od prijašnjih generacija koje su se držale pravno valjanih djela u svim aspektima, bez pokuđenosti, a mjerilo toga je bio sunnet Poslanika, a.s., tako da šejhul-islam Ibni Tejmije kada govori pozitivno o lijepom nijetu onih koji su pristalice mevludskog praznikovanja, govori o tome samo iz razloga što je lijep nijet osobe, makar mu djelo bilo i novotarija,

\footnotetext{
${ }^{57}$ Ibn Tejmije, Iktidaus-siratil-mustekimi limuhalefeti ashabil-džehim, 2/126. 58 Ibid., 2/190.
} 
bolje nego da se potpuno otuđi i odrodi od vjere. Prema tome njegov stav je:

Onaj ko bude imao lijep, ispravan nijet, biće nagraden za njega, makar djelo koje uradi i nije šerijatsko, ako mu namjera nije bila da kontrira Śerijatu. ${ }^{59}$

\section{Zaključak ili preferirano mišljenje}

Govoriti o Mevludu sa šerijatsko, pravnog aspekta, zbog njegove prirode, nije samo dati i proklamovati šerijatski propis dozvole ili zabrane, nego podrazumijeva da se u njegovom razmatranju i eksplikaciji uzme u obzir sadašnji kompleksni aspekt i njegova tradicijska, običajna, civilizacijska i kulturna vrijednost uz podsjećanje na nekoliko aksioma:

1. Općeprihvaćeno i općepoznato je da obilježavanje i sjećanje na Mevlud, rođenje i rođendan Allahovog Poslanika, a.s., kao vjerski obred i čin nema osnovu u Kur'anu i sunnetu; kao obred nije postojao u vrijeme Allahovog Poslanika, a.s., niti u prva tri najvrijednija stoljeća islama. Prema tome proslava Mevluda nije postojala u vrijeme ashaba, tabiina i tebiu't-tabiina, iako se radi o uzoritim, pravovjernim generacijama selefus-saliha, koje su najispravnije slijedile i najviše voljele Poslanika, a.s., bili njegovi najvjerniji i najgorljiviji sljedbenici. Također, ne smije se zaboraviti, da je u svekolikoj ovosvjetskoj kulturi sjećanja i pamćenja Uzvišeni Allah, dž.š., odredio da Njegov Miljenik i Poslanik, Muhammed, a.s., bude osoba koja će se doktrinarno (tevkifi) pamtiti i sjećati ga se kroz Božanski, nenadmašni sistem, svakodnevno. Njega spominje i sam Uzvišeni Allah i Njegovi meleki, kako je došlo u kur'anskoj normi, spomenut je i u Prvom temelju vjere, Šehadetu, odmah uz Božije ime i formulu monoteizma. Početak vjere nekog vjernika započinje sa Svjedočanstvom u kojem se pamti i izgovara ime Muhammeda, a.s., spomenuto uz samo Božije ime u formuli Šehadeta. Poslije toga to ime se svakodnevno pamti i izgovara svaki musliman praktičar izgovarajući ga u svojim dnevnim molitvama, kroz doktrinarne forme salavata, četrdesetak puta dnevno $u$ farz namazima $i$ vitrama i još toliko i više (46 puta) ako klanja i sve uobičajene namaske

${ }^{59}$ Ibid., 2/251. 
sunnete, kroz salavate koji se uče na sjedenju namaza. To svakodnevno sjećanje na ime i ličnost Muhammeda, a.s., započinje svakog dana, na sabahu, kada vjernik klanja sabah namaz pa se onda nastavlja i na podne, pa na ikindiji, na akšamu i na jaciji. Pored spomenutog pamćenja i sjećanja čini se i dodatno, javno sa minareta kao simbol da je neko mjesto muslimansko, pet puta dnevno, u islamskim mjestima i gradovima kada se razliježu riječi ezana, a onda i u ikametu unutar džamije ili porodičnih kuća sa kojim starta obavljanje farz namaza. Potom se ponovo ovo ime spominje u dovi iza ezana. Prema tome svaki vjernik od vremena kada postane vjernikom, primanjem islama ili punoljetstvom, ako je rođen $\mathrm{u}$ islamu, pamti, spominje i sjeća se Muhammeda, a.s., stotinjak puta svakodnevno do svoje smrti. Pomnožimo ovo sa članovima islamskog ummeta, koji je najbrojniji ummet na zemaljskoj kugli. Rezultat je fantastičan! Zaista, ako znamo da je islamski ummet, najbrojniji na zemaljskoj kugli, onda možemo otkriti da se ime Muhammeda, pamti, sjeća i spominje svakodnevno u desetinama ili stotinama milijardi puta. I to se ponavlja svaki dan, u istorijskom rasponu već preko četrnaest vijekova. Nijedan smrtnik, nijedno stvoreno biće, nije predmet ovakve kulture pamćenja i sjećanja kroz istoriju svijeta. Prema tome bespredmetno je dalje uopće raspravljati o tome, pored toga što se Muhammed, a.s. u kulturi pamćenja i sjećanja spominje stotine milijardi puta svakodnevno $\mathrm{u}$ islamskom ummetu po doktrinarnoj osnovi, bespredmetno je treba li uz to da se po ljudskoj inovaciji spominje i još jednom manifestacijom godišnje kao što je Mevlud - jer mevlud nije postojao u prva tri/četiri stoljeća islama. Ta rasprava je, kako god tretirali mevlud, kao lijep islamski običaj, što smatraju neki, ili kao zabranjenu novotariju, što smatraju drugi, ili kao manifestaciju koja može poslužiti u današnjem vremenu kao vid sjećanja i pamćenja na Misiju s kojom je došao Allahov Poslanik, a.s., uz ovo nebrojeno doktrinarno i praktično sjećanje na Muhammeda, a.s., koje svaki vjernik praktičar pamti i spominje Muhammeda, a.s., u svojim ibadetima, to je samo ono što zamagljuje ove doktrinarne činjenice i horizonte vjere tako da se od šume ne vidi drveće, odnosno od jednog slučaja ne vide se milijarde drugih. Zbog toga, kao što nema potrebe za kapi kiše u okeanu koja praktično ne doprinosi podizanju njegove razine, isto tako nema doktrinarne potrebe za još jednim sjećanjem na Muhammeda u vidu obreda Mevluda, godišnje, da bi se slijedili nečiji tuđi običaji. 
2. Naravno, i pored ove istine svake godine dolaskom mjeseca Rebiu'levvela, u kojem je rođen Allahov Poslanik, a.s., nanovo se aktualizira pravno šerijatski spor oko pitanja obilježavanja i slavljenja rođendana Muhammeda, a.s., na običajni, tradicijski način učenjem i organizovanjem proslave Mevluda, kojeg ortodoksna, puritanistička ulema drži zabranjenom, ružnom novotarijom i inovacijom u vjeri, koja se ne prihvata, jer je Uzvišeni Allah niti Njegov Poslanik, a.s., nisu uzakonili, nego su ljudi inovirali dan praznikovanja koji nije vjerom ustrojen, slijedeći običaje drugih, kao što su kršćani, nevjernici itd.; dok ga druga, savremena ulema drže lijepim i pohvalnim činom koji ima svoje opravdanje i koristi kroz praksu i ostvarivanje nekih dozvoljenih vidova valjanog ibadeta, kao što je učenje Kur'ana, salavata na Pejgambera, a.s., dova i zikra te podsjećanje na siru i životopis Muhammeda, a.s., kroz vjerska predavanje, vaz i sl.

3. Prihvatanje novotarija u Šerijatu značilo bi optužbu Poslanika, a.s., da nije dostavio upotpunjenu vjeru, kao što kaže imam Malik, r.h.t.: Ko inovira nešto u ovom ummetu na čemu nije bila generacija selefa, time tvrdi da je Allahov Poslanik, a.s., iznevjerio vjeru jer je Uzvišeni obavijestio: Danas sam vam vašu vjeru usavršio..., prema tome što nije bilo tada vjerom ne može biti ni danas.

4. Međutim, u isto vrijeme grupa uleme koja dozvoljava obilježavanje Mevluda i sjećanje na rođenje Poslanika, a.s., Mevlud tretiraju ne vjerskim obredom, nego vidom običajne proslave i u'rfa kojeg su ustalili i uveli muslimani iz ljubavi i volidbe Allahovog Poslanika, a.s. Ibni Tejmije, koji inače ne dozvoljava Mevlud kao vjerski obred, nada se da će oni za tu svoju ljubav i volidbu, biti nagrađeni, a ne za novotariju. Prema tome ako se u takvoj jednoj manifestaciji ne prakticiraju i ne pojavljuju zabranjene stvari i nedozvoljenosti, onda je takva manifestacija dozvoljena, i suprotno od toga, ako je taj običaj utemeljen na haramu i nedozvoljenostima onda ga Šerijat zabranjuje.

5. U našim, uvjetima ta manifestacija se može iskoristiti u obrazovne, odgojne i misionarske svrhe, kao izraz ljubavi i volidbe Allahovog Poslanika, a.s., i kao tradicija i običaj savremenog pamćenja i sjećanja na Allahovog Poslanika, a.s., njegovo učenje i njegovu Misiju, a ne da se koristi kao vjerska, obredna manifestacija, što je nažalost čest slučaj. 


\section{Izvori i literatura}

1. El-Kur'anu-l-kerim, Mushaful-Medinetin-Nebevijjeh (Kur'an Časni, medinska verzija Mushafa), (Mudžemme'ul-melik Fehd, 1405.h.).

2. Korkut Besim, Kur'an s prevodom, (Štamparija kralja Fehda, S. Arabija, Medina, 1412. h.).

3. Ahmed b. Muhammed b. Ebi Bekr b. Hallikan, Vefejatul-ea'jan ve ebnau ebnaiz-zeman, (Daru Sadir - Bejrut, 1972.).

4. Ahmed b. Muhammed b. Hanbel Eš-Šejbani, Musned (Muesseseturrisale, 1421/2001).

5. Ahmed b. Muhammed El-Kastelani, El-Mevahibul-ledunijje bilminehil-Muhammedijje, El-Mektebul-islami, 1425/2004.

6. Aid b. Abdullah El-Karni, Muhammed, a.s., kao da ga vidiš, ElKelimeh, Novi Pazar 2009.

7. Antun Hangi, Život i običaji Muslimana u Bosni i Hercegovini, Dobra knjiga, Sarajevo, 2009.

8. Bašagić-Redžepašić Safvet-beg (Mirza Safvet), Kratka uputa u prošlost Bosne i Hercegovine (od g.1463.-1850.), Sarajevo, 1900.

9. Bedruddin el-'Ajni, 'Umdetu-l-kari'i šerh Sahihul-Buhari, Darulfikr, Bejrut.

10. Bringa Tone, Biti musliman na bosanski način, Biblioteka Dani, 1997.

11. Džalaluddin Es-Sujuti, Odgovori, izbor fetvi, El-Kalem, Sarajevo, 1432-2011.

12. Ebu Abdullah El-Hakim En-Nejsaburi, El-Mustedreku a'lesSahihajni, Darul-ma'rife, 1418/1998.

13. El-Hummam (En-Nizam) i grupa učenjaka iz Indije El-fetava elhindijje fi mezhebi-l-imamil-e'azami Ebi Hanifeten-Nu'man (Indijske decizije u pravnoj školi imamu-l-e'azama Ebu Hanife enNu'mana, poznate i kao El-fetava el- 'alemkirijje) (Daru ihjait-turasi1-'Arebi, Bejrut, četvrto izdanje, bez godine izdanja), sa dodatkom još dvije knjige u istom kompletu-knjizi:Fetava Kadija han (Decizije Kadija Hana), i El-fetava el-bezazijje (Decizije Bezazija).

14. Hangi Antun, Život i običaji muslimana, Dobra knjiga, 2009.

15. Ibn Džerir Et-Taberi, Džami'u-l-bejan fi te 'vili aji-l-Kur'an, Daru-1Fikr, 1984.

16. Ibn Hadžer El-'Askalani, Fethul-Bari bišerh Sahihu-l-Buhari, Darur-rejjan lit-turas, Kairo, 1987. 
17. Ibn Kesir, Tefsir Ibn-Kesir, skraćeno izdanje, Izabrao najispravnije verzije Muhammed Nesib er-Rifa'i, Visoki saudijski komitet, Sarajevo, 2000.

18. Ibnu Redžeb, Ebul-Ferdž, Džamiu'l-u'lumi vel-hikemi fi šerhi hamsine hadisen min dževamii'l-kelimi, Daru Ibni Kesir, $1429 / 2008$.

19. Ibni Tejmije, Iktidaus-siratil-mustekimi limuhalefeti ashabil-džehim, bitahkik Nasir A'bdul-Kerim, Daru A'lemil-kutub- Bejrut, sedmo izdanje, 1419./1999.

20. Ibni Tejmije, Medžmu'u fetava, Izdanje kralja Fehda b. 'Abdulaziza, 1398.

21. Ibni Tejmije, El-furkanu bejne evlijair-Rahmani ve evlijaiš-šejtan.

22. Ibrahim b. Musa Eš-Šatibi, Ebu Ishak, El-I'tisam (MektebetutTevhid).

23. Ismai'l b. Muhammed El-A'džluni, Kešful-hafa'i ve muzilul-ilbasi a'mmaštuhire minel-ehadisi a'la elsinetin-nas (Darul-kutubilmasrijje).

24. Muftić Teufik, Arapsko-bosanski rječnik, El-Kalem, Sarajevo, 1997.

25. Muhammed b. Ahmed el-Kurtubi, El-Džamiu' liahkamil-Kur'an, Daru ihjait-turasil-'Arebi, Bejrut, Libanon, 1985.

26. Muhammed b Ebi Ishak En-Nefezi, Fetava Ehlu Ifrikija, velEndelus, vel-Magrib.

27. Muhammed b. Jusuf Es-Salihi Eš-Šami, Subulul-huda ver-rešadi fi sireti hajril-i'badi, Darul-kutubil-i'lmijjeti, Bejrut, 1414/1993.

28. Muhammed b. Rešid b. A'li Rida b. El-Husejni, Tefsirul-Kur'anilkerim/Tefsirul-Menar, El-Hejetul-Masrijje el-a'mme lil-kitab, 1990.

29. Muhammed b. Salih El-U'sejmin, Ěs-Šerhul-mumti'ua'la zadilmestekni'i, Dar Ibni Dževzi lin-nešri vet-tevzi'i.

30. Sulejman b El-Eša's, El-Ezdi, Es-Šidžistani, Ebu Davud, KitabusSunen, Darul-Kible, Muessesetur-Rejjan, El-Mektebetul-Mekijje, 1419/1998.

31. Tadžud-Din El-Fakihani, El-Mevrid fi amelil-mevlid, Darul-A'sime, 1419/1998. 


\section{Internet:}

1. لماذا نصلي على النبي صلى الله عليه وسلم؟

islamqa.infohttps://islamqa.info/ar/180852, (pristupljeno 10. januar, 2016.)

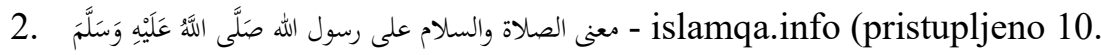
januar, 2016.)

3. فضل الإكثار من الصلاة على النبي صلى الله عليه وسلم /...

https://islamqa.info/ar/128455 (pristupljeno 10. januar, 2016.)

4. Mevlud www.becopdx.com/index.php/aktivnosti/mevlud (pristupljeno 10. januar, 2016.)

5. www.aljamaa.net/ar/document/65236.shtml, حكم الاحتفال بذكرى المولد النبوي - جماعة العدل والإحسان بقلم: عبد الله المومني (pristupljeno 06. januara, 2016.)

6. حكم الاحتفال بالمولد وفقاً لمذهب الإمام مالك.WWw.awqaf.ae (pristupljeno 03. januar 2016.)

7. www.aljamaa.net/ar/document/65236.shtml, حكم الاحتفال بذكرى المولد (pristupljeno 06. januara, 2016.)

8. http://www.qaradawi.net/site/topics/article.asp?cu_no=2\&item_no= $5852 \&$ version $=1 \&$ template_id=130\&parent_id=17, (pristupljeno 06. januar, 2016.)

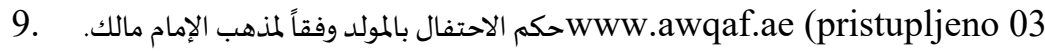
januar 2016.). 
Muharem Stulanovic, $\mathrm{PhD}^{60}$

\section{AL-MAWLID BETWEEN A GOOD TRADITION (AL-SUNNAH AL-HASANAH) AND A PROHIBITED INNOVATION (AL- BID'AH AL-SAJJIAH)}

\section{Abstract}

In the Muslim tradition, month of Rabi'al-Awwal has been devoted to remebrance and memory of the prophet Muhammad, peace be upon him, through special programs, or so called Al-Mawlids every year.

Each year with the arrival of the month Rabi'al-Awwal, in which Muhammad, peace be upon him, was born, we have legal Shariah discussions over the issue of marking and celebrating the birthday of Muhammad, through organizing celebrations of Al-Mawlid. Orthodox, puritanistic scholars state that Al-Mawlid is a forbidden, ugly novelty and innovation in religion (AlBid'ah Al-Sajjiah), which was invented as a festival day because of blind imitation of others, like Christians, nonbelievers etc. The other, contemporary scholars have an opinion that Al-Mawlid is a good and commendable act (AlSunnah Al-Hasanah) which has its justification and is applied through the practice and achievemnt of certain permissible forms of worship, such as recitation of the Quran, sending salutations and blessings upon Muhammad, peace be upon him, reciting prayers and dhikr and a reminder about the Seerah, ie. biography of Muhammad, peace be upon him, through religious lectures, speeches, etc.

In modern terms, this event can be used in our mosques and community in educational and missionary purposes, as an expression of love for Allah's Messenger, and as a tradition and custom of modern memory and remembrance of Allah's Messenger, his teaching and his mission. Al-Mawlid should not to be taken as a religious, ceremonial event, which is unfortunately often the case in practice.

Keywords: Al-Mawlid, ugly innovation (Al-Bid'ah Al-Sajjiah), a good tradition (Al-Sunnah Al-Hasanah), scholars, the culture of memories, tradition, habit.

${ }^{60}$ Faculty of Islamic Pedagogy in Bihac 


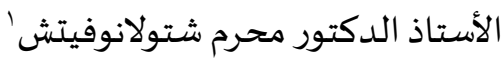

\section{المولد النبوي بين السنة الحسنة والبدعة السيئة}

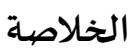

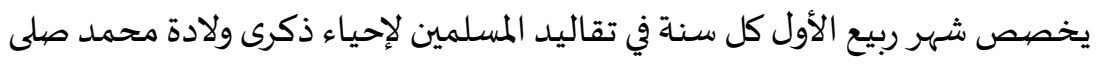
الله عليه وسلم من خلال البرامج المناسبة.

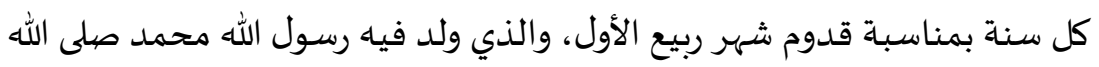

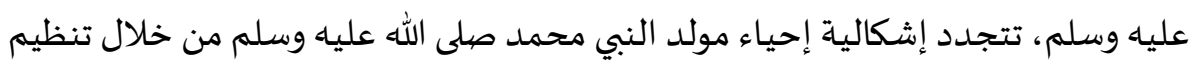

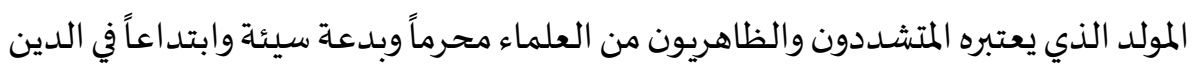

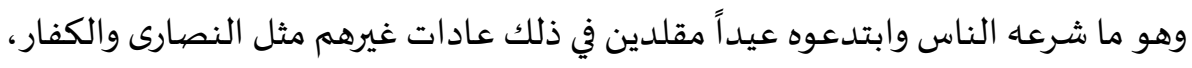

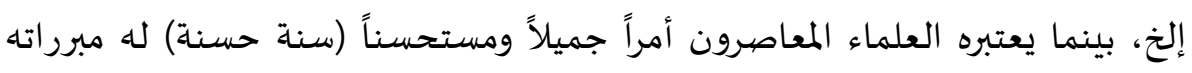

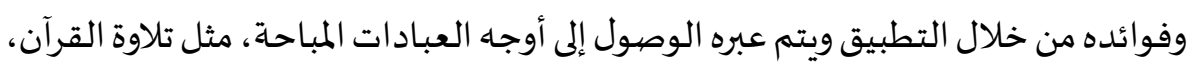

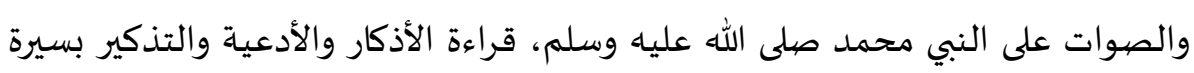

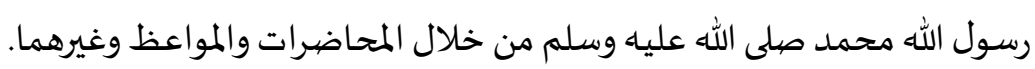

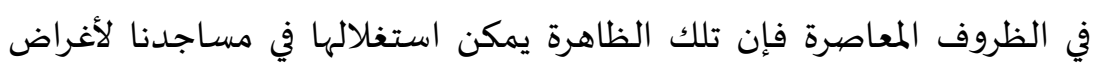

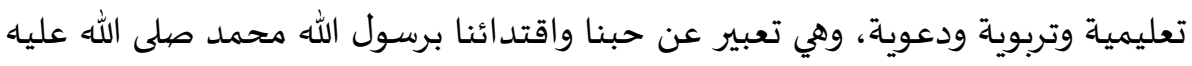

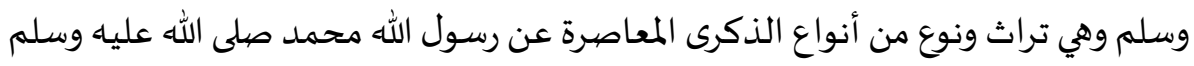

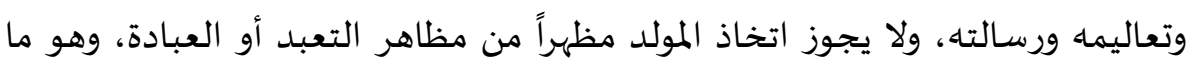
يحصل وبكثرة مع الأسف من خلال التطبيق.

الكلمات الرئيسة: المولد، البدعة السيئة، السنة الحسنة، العلماء، ثقافة التذكر،

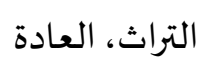

' الأستاذ في كلية التربية الإسالامية في بيهاتش 